\title{
Secondary Materials in Domestic Refuse as Energy Sources
}

\section{Europool \\ Communication Consulting Research in Europe}

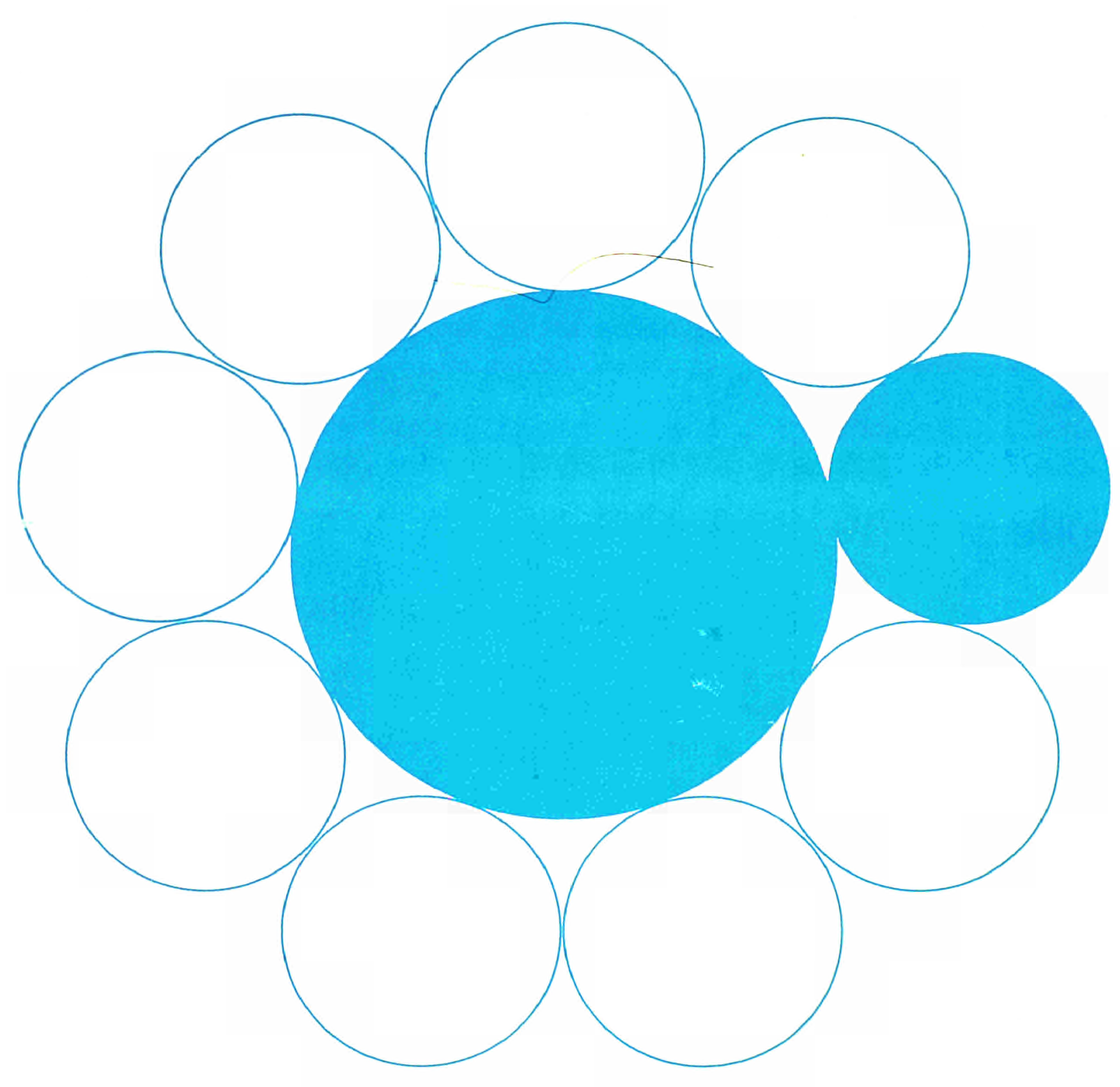

Published by Graham \&ீ Trotman Limited

for the Commission of the European Communities 



\section{Secondary Materials in Domestic Refuse as Energy Sources}

\section{Europool \\ Communication Consulting Research in Europe}

A report prepared for the Environment and Consumer

Protection Service of the Commission of the

European Communities by Europool

Published by Graham \&o Trotman Limited for the Commission of the European Communities 
Published in 1977 by

Graham \& Trotman Limited

20 Fouberts Place, Regent Street

London W1V $1 \mathrm{HH}$, United Kingdom

for the Commission of the European Communities

Directorate - General Scientific and Technical Information

and Information Management, Luxembourg

(CECSC, EEC, EAEC, Luxembourg, 1977

\section{ISBN 00860100642}

\section{Legal notice}

Neither the Commission of the European Communities, its contractors nor any person acting on their behalf: make any warranty or representation, express or implied, with respect to the accuracy, completeness, or usefulness of the information contained in this document, or that the use of any information, apparatus, method or process disclosed in this document may not infringe privately owned rights; or assume any liability with respect to the use of, or for damages resulting from the use of any information, apparatus, method or process disclosed in this document.

All rights reserved. No part of this publication may be reproduced, stored in a retrieval system, or transmitted in any form or by any means, electronic, mechanical, photocopying, recording or otherwise, without the prior permission of the publishers. 


\section{CONTENTS}

\section{Page}

Introduction

The incidence of waste 4

The question of quantity 4

$\begin{array}{ll}\text { Problems of collection } & 12\end{array}$

$\begin{array}{ll}\text { The composition of the waste } & 15\end{array}$

A tentative summing up 25

Waste as a source of energy 33

Domestic waste in place of oil? 42

Domestic waste no substitute for oil 47

The production of energy from sewage sludge 48

The technical background 51

An introduction to waste incineration 51

The various methods of waste incineration 54

The metallurgical use of waste 58

Pyrolysis processes $\quad 59$

The combined use of sewage sludge 65

Heat utilization in waste incineration 67 



\section{A LISTING OF.MATERIALS OBTAINED FROM DOMESTIC WASTE WHICH MAY BE USED AS SOURCES OFENERGY}

\section{Introduction}

Domestic waste and sewage sludge are by-products of human habitation which over past years have constantly been on the increase in the nine member countries of the European Communities. Up until the time when energy shortages began to make themselves felt public discussion about domestic waste concentrated almost exclusively on its 'disposal', i.e. the idea was to 'get rid of' waste and sewage sludge. The possibility of recycling this material

either for the purpose of generating energy, making compost or simply salvaging useful constituents for reintroduction into the manufacturing process was relegated far into the background. It needed the so-called 'energy crisis' to concentrate more attention on the question whether waste products, for which some means of disposal had to be found in any case, should not be put to greater use in the production of energy. This I ine of reasoning found support, particularly in the Federal Republic of Germany, in a number of incinerating plants whlch had for decades past been burning waste, and to some extent sewage sludge as well, in order to produce thermal energy. The experience acquired in operating these plants is especially valuable, since many questions relating to the generation of energy from waste still await a final answer.

In its broadest sense the question of producing energy from waste also embraces the issue of how energy can be saved by using waste products. To take an example, from blast furnace to steelworks the manufacture of a tonne of crude steel consumes 5.8 gigacalories (Gcal). On the other hand, if steel is produced in electric furnaces from scrap then one tonne of crude steel 
requires only $1.5 \mathrm{Gcal}$. This amounts to an important saving of energy, and similar calculations could also be made for recycled paper and glass.

However, it is not our intention in the present study to deal with the production of energy from waste in this extended sense. Nevertheless, in the approprlate place, it will be proper to make some comparison between the alternative uses of waste when we come to consider the balance of energy consumed against the energy generated using waste as a fuel. We may remark at once that, by comparison with the classical fossil fuels (coal, lignite, mineral oll and natural gas), waste necessitates a relatively high consumption of energy in order to release that which it itself contains.

It is conceivable to generate energy from domestic waste and sewage sludge in a number of different ways:

1. By the direct release of heat energy through incineration, the heat being used for:

1) The generation of electricity

2) Long-distance heating, or

3) Supplying process heat to industry

11. By manufacturing homogeneous fuels through:

1) Gasification of waste,

2) Liquefaction of the waste,

3) Waste carbonization, or

4) Gas production by putrefaction, chiefly of sewage sludge.

The term 'pyrolysis' is used when talking about the gasification or liquefaction of waste. While sufficient information is already available regarding incineration, pyrolysis is still at the stage of laboratory and large-scale testing. In the course of this study we shall have to consider the processes themselves in some detail.

The purpose of this investigation can only be fulfilled in a meaningful way if account is also taken of the national economic interest. If we were concerned to produce energy from domestic waste no matter what the price, that is to say without having regard to the overall cost to the national economy, then the question we have posed ourselves would be superfluous. The only question to be consldered in that case would be how much energy could be produced from waste in terms of its equivalent in tonnes or barrels of oil. However, it is quite conceivable that, in order to produce a given amount of 
energy from waste, a quantity of resources would have to be employed whose calorific equivalent would exceed the heat value of the energy actually generated. The question would then arise whether it would not be more reasonable to devote these resources to securing energy supplies either from our own sources or from politically crisis-free and relatively stable areas of the world.

At all events, this is a question to be posed and answered within the political sphere. The present study can only provide food for thought. 



\section{The question of quality}

As used in this study, the term 'domestic waste' embraces the waste generated by homes and small businesses (traders, workshops and light industry) and excludes all clearly specialized or industrial waste. The waste originating from hospitals and livestock establishments, for example, is therefore not included. On the other hand, account must be taken both of used oil products and old tyres, although worn out motor vehicles are dealt with in a separate study. Street refuse is treated in a statistically non-uniform manner. To the extent that it contains combustible material it may be of considerable interest to this study. We may suppose that it is removed by the public refuse disposal authorities together with household and business waste.

The incidence of waste per head of the population depends on a number of factors. Provided certain conditions are met, a remarkable degree of consistency is found in the figures irrespective of the country concerned. Basically, the following factors are of decisive importance:

1) Density of population. Centralized waste collection is vital in densely-populated areas. In contradistinction to country districts with a sparse population, no waste can be dumped by individuals in the countryside. Although this practice has already been prohibited in all the countries of the Community it stlll happens often enough, as the evidence of our eyes bears witness. 
2) The pattern of economic activity. This is directly linked to the population density. In rural areas, apart from the illegal dumping of rubbish, it may, if combustible, be used for heating purposes, e.g. for heating stables, or otherwise be used for the preparation of cattle fodder.

3) Heating habits. In Community countries there has been a universal tendency, varying only in degree, for oil and gas heating, chiefly in the form of central heating, to gain ground against heating by means of individual stoves burning coal and lignite. This remarkable development influences greatly the specific weight of the waste but affects first and foremost its calorific value. We shall have to deal with this in greater detail when considering the question of heating values.

4) The standard of living. This factor must be considered in the context of those already mentioned, for a rise in the living standard has in all countrles gone hand in hand with urbanization and an increasing concentration of the population in congested centres. This has been accompanied by simultaneous industrialization at the expense of agriculture and, what is more, the rise in the standard of living has brought about a change in heating habits. In other ways, too, the rising standard of living is having a significant effect on both the quantity and the quality of waste matter: prepacked food for selling in self-service stores and other consumer goods mean more packaging materlal made of paper, plastic, glass, tinplate and aluminium foil. The average calorific value increases with the incidence of paper and pasteboard, but drops in response to the proportion of glass and metal.

We may sum up what has been said in the following terms: both the quantity and the calorific value of waste are at their lowest in rural areas with a poorly developed infrastructure. They attain their maximum values in large cities and the surrounding catchment areas.

This thesis can be supported by figures. For example, in NordrheinWestfalen* (see the Federal Government Report on the Environment) the following incidence of waste was ascertained in relation to the size of the community. Table I shows the connection between the size of the community and the specific per capita generation of waste. 
Table 1

The Incidence of Domestic Waste in the Federal Republic of Germany in 1971

Size of Community

No. of inhabitants
of Fed. Rep. of
Germany.

1,000 s
Quantity of Domestic Waste

Per head in Nordrhein-

Westfalen in 1971

$\mathrm{kg}$

$m^{3}$
(Projected) Incidence of Domestic Waste in the Fed. Rep. of Germany

$1,000 \mathrm{t}$ $1,000 \mathrm{~m}^{3}$ a Less than 20,000

20,000 to less than

50,000

50,000 to less than

100,000

100,000 and over

Total
29,591

7,179

4,238

19,643

60,661
189

0.805

5,593

23,820

213

1.009

1,529

7,244

239

1.230

1,013

5,213

265

1.457

5,205

28,620

234

1.190

13,340

64,897 
It is Interesting to compare these figures with those reported by Straub (A Report Concerning the Disposal of Solid Waste Products Generated by the Community and by Industry, Oldenbourg, Munich, 1962) especially since these latter figures are ten years older. It is apparent from these that, over the period of time in question, there was hardly any significant change in the speclfic values. Straub arrives at the following relationship between the slze of the communlty and the per capita incidence of waste:

Table 2

Size of Community and Incidence of Waste in Germany

$\begin{array}{ccc}\text { No. of Inhabltants } & \text { Amount of Waste } & \text { Amount in } \\ \text { in the Community } & k g \text { per head per } & 9 \text { per head } \\ & \text { year } & \text { per day }\end{array}$

$\begin{array}{lll}\text { Below 2,000 } & 100 & 275 \\ 2,000-5,000 & 160 & 440 \\ 5,000-20,000 & 180 & 500 \\ 20,000-100,000 & 200 & 550 \\ 100,000-500,000 & 220 & 600 \\ 500,000-1,000,000 & 240 & 650 \\ \text { Over } 1,000,000 & 260 & 710\end{array}$

Information relating to the Republic of Ireland (Department of Local Government, Custom House, Dublin) provides similar figures:

Table 3

Size of Community and Incidence of Waste in Ireland

No. of inhabitants

Dublin City

568,000

Dub I in County

Cork

LImerick

Republic of Ireland overall
231,000

129,000

57,000

$1,870,000$
Waste per head

t

$\mathrm{kg}$

264

260

256

246

$\begin{array}{ll}150,000 & 264 \\ 60,000 & 260 \\ 33,000 & 256 \\ 14,000 & 246\end{array}$

479,000

256 
The figures relate to communities with waste collection and disposal systems. This 'selection' may account for the relative consistency of the figures irrespective of the size of the community.

To complete the picture we list below a number of cities together with their speciflc rates of waste generation:

Table 4

Quantity of Waste Per Inhabitant Per Year in Various European Cities

$\begin{array}{lr}\text { Great Britain (average values) } & 280 \\ \text { Suburban areas with numerous gardens } & 250 \\ \text { Edinburgh } & 210 \\ \text { The Netherlands (average values) } & 270 \\ \text { The Hague } & 275 \\ \text { Groningen } & 250 \\ \text { Switzerland, Zurich (for incineration only) } & 170 \\ \text { Basle } & 164 \\ \text { Lausanne } & 190 \\ \text { City of Luxemburg } & 400 \\ \text { France, Paris (1960) } & 290 \\ \text { Bordeaux } & 315\end{array}$

\section{Source: Handbook on Waste}

If, instead of the weights given above, we ask how the volume has developed, the point may be made that the question of volume is less important from the incineration point of view than in its bearing on the collection of waste. Furthermore, according to Ferber ${ }^{\prime)}$ establishing volumetric data is not without its problems since the same amount of waste produces widely varying results depending on the stage reached in its handling: either before or after loading into the waste collection vehicles. It is true that the specific weight of the waste may provide some clues as to its calorific value.

1)Dipl.-lng. Michael Ferber, Die Mengen der festen Abfallstoffe

(The Quantitative Assessment of Solid Waste), in the Handbook on Waste. 
A high molsture content, for instance, raises the bulk density and, at the same time, reduces the calorific value. The same applies to ashes (from domestic heating systems), glass, china and ceramic materials. With certain reservations, the following rule of thumb may be stated: the higher the specific weight, the lower the calorlfic value. With the elimination of individual coal fires, In which organic waste and paper could be reduced to ashes, the specific weight of the waste has, as a rule, also dropped. So far as the overall costs of producing energy from waste are concerned this has the further consequence that a lower specific weight implies the use of a greater amount of transport to carry the same tonnage.

It is our intention to try to determine mathematically the quantities of waste which may be assumed given a specific mean rate of waste generation per head of the population. We base ourselves on the practical recognition that overall calculations relating to large regions or whole countries can only be arrived at by projecting mathematically numerical data established in relation to particular cases. It must be made clear that the values determined in this way are hypothetical in character. Beginning with a quantity of $150 \mathrm{~kg}$ of waste per year per head of the population we shall examine the theoretically possible orders of magnitude up to a specific incidence of waste of $320 \mathrm{~kg}$ per head per year. We should point out at once that global calculations of this kind cannot be applled directly to the determination of corresponding amounts of energy. Only a part of the total quantity calculated as being theoretically disposable can, in any case, be used for the production of energy, no matter what form this takes. Primarily, this is a question of distances and population density. To take two examples, it would make nonsense for the purpose of generating energy to transport waste from the Bavarian Forest or the Central Massif of France over a distance of more than $300 \mathrm{~km}$ to reach an incinerating or gasification plant. The energy consumed in transporting the waste would itself more than outweigh the expected energy yield. Individual locations where centralized collection is reasonable, and the feasible radius of operation, are questions which must be resolved by studying regional conditions. Our initial objective, of course, is to provide a survey of global figures arrived at mathematically.

The average incidence of waste (the geometrical mean value) can be calculated from Table 5 as $227 \mathrm{~kg}$ per year per head of the population. For the nine member countries thls is equivalent to $57.86 \mathrm{milli}$ ion tonnes of waste. It is not improper to use these figures for working hypotheses relating to the future since the limits of growth in the generation of waste are becoming 
Table 5

Total Amounts of Domestic Waste Generated (in thousands of tonnes) on the Basis of Assumed Figures for the Annual Incidence of Waste per Head

\begin{tabular}{lrrrrrrr} 
& $150 \mathrm{~kg}$ & $\underline{180 \mathrm{~kg}}$ & $\underline{200 \mathrm{~kg}}$ & $\underline{230 \mathrm{~kg}}$ & $\underline{260 \mathrm{~kg}}$ & $\underline{300 \mathrm{~kg}}$ & $\underline{320 \mathrm{~kg}}$ \\
\cline { 2 - 8 } & 9,251 & 11,101 & 12,334 & 14,185 & 16,035 & 18,502 & 19,735 \\
Germany (Fed. Rep.) & 7,761 & 9,314 & 10,348 & 11,901 & 13,453 & 15,523 & 16,557 \\
Italy & 8,152 & 9,782 & 10,869 & 12,499 & 14,130 & 16,304 & 17,390 \\
The Netherlands & 1,999 & 2,399 & 2,666 & 3,066 & 3,466 & 3,999 & 4,266 \\
Belgium & 1,457 & 1,748 & 1,942 & 2,234 & 2,525 & 2,913 & 3,108 \\
Luxemburg & 53 & 63 & 70 & 81 & 91 & 105 & 112 \\
Great Britain & 8,368 & 10,042 & 11,158 & 12,831 & 14,505 & 16,736 & 17,852 \\
Ireland & 452 & 543 & 603 & 693 & 784 & 904 & 964 \\
Denmark & 750 & 900 & 1,000 & 1,150 & 1,300 & 1,500 & 1,600 \\
& & & & & & & \\
& 38,243 & 45,892 & 50,990 & 58,640 & 66,289 & 76,486 & $\varepsilon 1,584$
\end{tabular}


more and more apparent. At the same time, in those countries with a lower level of Industrlalization and where the infrastructure is still lagging behind we must expect a more rapld rate of growth for a number of years to come.

At this polnt attention must be drawn to one fact: within the terms of the questions under investigation here, i.e. the potential production of energy, the Republic of Ireland can be disregarded even on the basis of the data presented here. The amount of waste projected for the entire population, even when the highest per capita figure is applied, is not adequate to justify the generation of energy by this means. Furthermore, the waste, which is insufficlent in quantity in absolute terms, would have to be transported over excessive distances. 


\section{Problems of collection}

Before considering in detail the possible ways of processing household waste, and that produced by small-scale businesses which is also our concern, we must look at the methods of collection, since, in certain circumstances, these may determine at the outset the subsequent method of dealing with the waste for the production of energy. Similarly, the technique of waste collection employed may immediately rule out certain possibilities. Up to the present time systems of non-selective, bulk collection predominate in all the countries belonging to the community. This means that in the refuse collecting vehicles, irrespective of their design, everything is mixed together which occurs as household or business waste in the area being serviced. Whether, in this operation, the waste is transferred from bins, containers or bags or in some other way is only of secondary importance. The sole significant fact is that a conglomerate is created in the refuse collecting vehicle. Often this conglomerate is compressed inside the vehicle itself. Naturally, this compressing operation is not so drastic as to rule out subsequent mechanical separation of the waste in order to facilitate the recycling of certain of its constituents.

Notwithstanding the fact that, throughout the European Economic Community, there is a clear predominance of conglomerate in refuse collecting vehicles, attempts are being made in all countries in the interests of easier recycling, to sort out immediately for this purpose certain constituents of the waste without allowing them to become mixed up in the conglomerated mass in the first place. The materials chiefly concerned are: 
glass, paper, textile waste and scrap metal. On the basis of our experience so far such sorting at the points where the waste is generated appears to be feasible to some extent given proper organisation and motivation of householders. The system does, however, involve considerable expenditure in the form of contalners, transhipment and transport facilities, which could only be justified if the prices of the recycled materials were extremely high. This cannot, however, provide a justification of the system over extended periods of time. Irrespective of the price levels for recycled materials, the system comes up agalnst a natural limitation in congested urban areas where, on the grounds of rationalization, some form or other of non-selective refuse disposal is imposed by circumstances which allows no room for subsequent differentiation. The simplest and, up the the present time, the most frequent form of such disposal arrangements is exemplified by the refuse shaft in multi-storey buildings, which empties into a large container.

If each storey is only provided with a single point of access to the shaft, any sorting of the waste is impracticable as the multi-storey building meets none of the prior conditions required for this. The same applies to those cases in which vacuum waste disposal plants are currently being built or planned to serve whole streets and housing blocks. The sole aim of this costly investment is to achieve by mechanical means a drastic reduction in the intensive labour requirements of conventional systems of refuse collection. Any separation of the waste into its constituents at the point of origin would run completely counter to this objective. Considered strictly in terms of the nation's economy, the saving due to the reduced manpower and energy requirements must be weighed against the concomitant disadvantage that, later on, the waste cannot be separated so easily into its various components as if this operation had been performed before they were made into a conglomerate.

Turning aside for a moment from the present day conglomerate carried by refuse collecting vehicles, from preliminary sorting in the home and the various types of refuse disposal systems imposed by force of circumstances, we now have to consider another variety of waste disposal in which the waste is compressed at its point of origin. We refer to the garbage presses for household waste which have already been installed in their millions in the United States but which, inside the European Economic Community, are still only available to the would-be purchaser in quite modest numbers in areas with a particularly high living standard. The garbage press collects in a plastic bag the waste generated in the home and compresses it by means of a 
motor-driven ram into a quarter or a fifth of its original volume. The capacity of the plastic bag is designed to take the average weekly waste produced by a residential group of three people. Where the amount of waste is greater, it must be compressed several times a week. The compressed waste can then either be placed in conventional bins or containers, or may simply be deposited at the roadside without further covering. The advantage of this method to those responsible for sanitation and refuse disposal lies in the great reduction in the volume of waste which has to be transported. Fewer journeys are required. According to studies carried out so far this produces a tangible benefit only when entire residential districts have been provided with domestic garbage compressors. Till now the snag here has been the capital cost. One solution would seem to be to equip each dwelling unit in new residential estates with garbage compressors as a matter of course. The economic advantages of compressing waste, which are reflected in a concrete manner in the savings made by local authorities, must be weighed against the investment and operating costs of the compressors (which have to be borne by the public) and the disadvantage that the subsequent breakdown of the compacted waste for the purpose of recycling certain of its constituents is only possible within certain limits.

Whatever may be the future development within the EEC of refuse disposal in high density urban areas and of garbage compressing techniques, we must for the next few years accept the basic fact that conglomerated waste of the traditional kind will continue to predominate in all the member countries of the Community. So far as its composition is concerned, this constitutes a thoroughly heterogeneous fuel, which is indeed inevitable with household and business waste. So far as waste incineration is concerned, this is reflected in the fact that grate type firing plant has to be used which has long since been superseded in other areas, for instance in coalburning equipment. We shall consider the technical aspects of waste Incineration in greater detail later on. 


\section{The composition of waste}

The potential value of waste for the production of energy depends on its composition. This again is the result of a number of determining factors, which we shall look at individually in relation to the most important constituents.

1) Paper and packaging material. The main sources are newspapers, perlodicals and packaging material. Its occurrence depends chiefly on the type of heating used in homes. The larger the proportion of individual coal fires in the overall heating pattern, the smaller will be the amount of waste paper which passes unburnt into the refuse disposal system. We therefore find a marked seasonal variation, more being burnt in winter than in summer. In the case of paper, the living standard is another important factor. Like the quantity of packaging material, the consumption of newspapers and periodicals is also a function of urbanization and an advanced living standard. Attention also needs to be paid here, of course, to the replacement of some packaging materials by others: paper and board, 9 lass, plastics and metal. In towns with large retail outlets (department stores, cash and carry markets and supermarkets) an important part is played by the waste packing materlal generated by these businesses. Another decisive factor determining the amount of paper entering the refuse system is the waste paper market.

If the prices paid for waste paper, which are normally subject to wide fluctuations, are sufflciently high to warrant collection and sale to the 
waste paper trade, then a considerable proportion of the paper is fed back into the waste paper industry and by-passes the refuse disposal system. The behaviour of the market from mid-1973 to autumn 1974, was characteristic of this phenomenon. During this time the price of waste paper in all the countries of the Community rose to such heights that the collection of waste paper assumed significant proportions. This was an important contributory factor to the situation observed in several large waste incinerating plants where the calorific value of the waste, after having risen consistently over the preceding years, stagnated in 1973 and 1974, and even fell slightly on occasion.

From what has already been said it can be easily deduced that the proportion of paper and board contained in waste can only be stated in terms of rough average figures. Reports from Belgium refer to a 31 per cent proportion of paper there. According to a waste analysis carried out in summer 1974, by the Dusseldorf Sanitation and Refuse Disposal Authority paper accounted for a 27.8 per cent share. Here the proportion has risen from year to year with the decrease in the number of individual coal fires. Ten years previously the figure was as low as 12-15 per cent. A report on the refuse recycling plants of the City of Rome (D. Stickelberger/IRC - WHO and W. Hoser/ Campaign for a Clean Switzerland, November 1973) puts the proportion of paper and board waste at around 30 per cent. Here, too, then the values arrived at are similar. For the City of Aachen, Hoberg and Schulz (Mull and Abfall - Waste and Refuse, 8/74) give an average figure of 30.8 per cent for paper and light board. For the Federal Republic of Germany the average figure is stated to be 28 per cent with a range of variation from 20 - 35 per cent.

In this connection the Dusseldorf data will be of some interest. A waste analysis performed in summer, 1974, produced the following figures:

Table 6

Analys is of Waste from Dussel dor.f, 1974

Organic waste

$34.19 \%$

Wood

$0.59 \%$

Paper

$27.75 \%$

Textiles

$3.11 \%$

Plastics

$6.22 \%$

Coal

$3.91 \%$

Glass

$16.40 \%$ 
(Table 6 cont Inued)

Rubble

Iron and Steel

$4.00 \%$

Non-ferrous metals

$0.38 \%$

Paper has a calorific value of $3,600 \mathrm{kcal}$ when dry. This is equivalent to about half the calorific value of coal.

Another application for waste paper is currently being studied in the Federal Republic of Germany, and it is of no consequence here whether the paper is separated at the point of origin or extracted later by mechanical means from the waste conglomerate for the purpose of recycling. This concerns the burning of waste paper in coal fired power stations. For some time past the United States has been using waste paper as a source of energy in coal fired power stations. The reason for this trend in that country lies in the fact that, in America, there are far fewer alternative uses of waste paper than in Europe. The overwhelming majority of American paper mills have been built in forest regions far from the towns. This means that in some cases waste paper would have to be transported over very long distances to the paper mills - usually an uneconomic procedure. From the start, therefore, burning the paper suggested itself as a solution.

As a fuel, waste paper possesses an unusual advantage: it is completely free of sulphur. So by adding waste paper to the coal burnt in power stations it is possible to reduce the average sulphur content of the waste gases. On the one hand this can be done quite intentionally on those days when there is a danger of smog in the vicinity of the power station and, on the other hand, if waste paper is fed into the power station fuel supply on a regular basis, then the gas cleaning plant can be scaled down accordingly. This latter factor naturally acquires importance primarily in the construction of new power station capacity. Thanks to this absence of any deleterious environmental effects, waste paper is burnt in power stations in the U.S.A. even when the price of waste paper is sufficiently high to cover completely the cost of collecting it.

2) Organic kitchen waste. Here, too, seasonal variations occur. We can accept at the outset that the proportion of tinned food in the diet is less in the countryside than it is in towns. Nonetheless, even in towns the amount of organic waste will be greater in summer than in winter. According to different data it will account for between 12 - 18 per cent of the waste. Rome, indeed, is an interesting case, where the organic waste is 
put at 45 per cent. The difference may be put down to climatic factors (heating habits; and perhaps also to a different diet (less tinned food, more fruit and vegetable consumption). Because of its widely varying moisture content, the calorific value of organic waste cannot be stated precisely. When dry, the heating value is somewhat lower than that of paper.

3) Textiles, rubber and plastics. All three groups account for only a relatively small proportion of the waste, while at the same time being combustible constituents. To a large extent textiles can be compared, chemically, with plastics. The proportion of plastics is nowadays put at $2-4$ per cent. Opinion is divided as to whether this is likely to increase substantially. Any increase in the proportion of plastics and textiles should raise the average calorific value of the waste. The calorific value of these two groups on their own may be put at 3,600 to 4,500 kcal $/ \mathrm{kg}$. Basically, rubber finds its way into the refuse disposal system via small businesses in the shape of used motor car tyres. Burning presents no technical probiems. The calorific value is much higher than that of paper, wood, textiles and plastics and may be put at 4,700 to 4,900 kcal. At the same time, tyres should be chopped up before burning. What is more, in the long run they are likely to prove more suitable for pyrolysis than for burning. A further factor is that the quantity of used tyres is very small wher considered in relation to waste as a whole. (cf. The Recovery of Metal waste from old Cars and Large Household Appliances: A study carried out on behalf of the commission, $\left(974^{1)}\right)$. A figure of 1.7 million tonnes is anticipated for the whole of the Community in 1980, while the figure for 1975 is about $1.4 \mathrm{mil}-$ lion tonnes. In relation to a total quantity of waste of between 50 and 60 million tonnes annually this corresponds to a proportion of about 2.5 per cent, always provided that the tyres are included in the refuse disposal system. However, with tyres in particular this is seldom the case.

4) Garden refuse. From the standpoint of its calorific value, this can be placed between paper and kitchen waste. It occurs of necessity as a feature of city waste since burning is usually impossible (with oil or gas heating systems) and few people make compost in the garden. Its share in the overall waste picture is very small. Exact information is not available,

1) Published as part of this series by Graham \& Trotman 
especlally as, in the nature of things, seasonal variations are considerable.

5) Non-combustible materials. These include glass, ferrous and non-ferrous metals, sand, rubble and ceramic materials as well as ash and slag. These materlals inhibit combustion and absorb heat energy. The calorific value of the waste rises or falls in inverse proportion to the quantity of these materials contalned in the waste. Two constituents play a particularly Important role here, one being glass and the other ash and slag considered together. The proportion of slag and ash contained in waste has fallen continuously, whlle the quantity of glass has risen with equal regularity.

The clearest yardstick for measuring the ground lost by the individual fire, which is not only suitable for burning rubbish but also simultaneously determines the amount of ash in the waste, is provided by the figures for the supply of coal to households and small-scale consumers in the countries of the Community. Taking the 1960 deliveries as 100, the following picture emerges for the nine countries:

\section{Table 7}

$\frac{\text { Trends in the Supply of Hard Coal to Households }}{(1960=100)}$

(average values for periods shown)

\begin{tabular}{|c|c|c|}
\hline $1965-1967$ & $1968-1970$ & \\
\hline
\end{tabular}

Germany (Fed.

Repub| ic)

France

Italy

Netherlands

Belglum

Luxemburg

G十. Britain

Denmark
71.2

95.7

77.0

87.7

94.6

52.4

75.8

39.9
67.7

80.0

66.5

53.4

87.5

32.0

61.4

32.8
42.1

55.8

25.7

17.1

57.6

12.9

43.7

17.1

In each case the average figure for three years has been taken to compensate for the effect of variable winters and is shown in tables $8-10$. 
Table 8

Deliveries of Hard Coal to Households (Excluding Supplies of Coke) $(1,000 \mathrm{t})$

\begin{tabular}{lccccccc} 
& $\begin{array}{c}\text { Germany } \\
\text { (Fed. Rep.) }\end{array}$ & France & Italy & Netherlands & Belgium & Lux. & UK \\
\hline 1960 & 4,225 & 8,472 & 1,432 & 3,302 & 4,734 & 98 & 37,547 \\
1961 & 4,079 & 8,669 & 1,513 & 3,329 & 4,985 & 93 & 35,941 \\
1962 & 4,446 & 9,292 & 1,472 & 3,994 & 5,595 & 96 & 35,460 \\
1963 & 5,521 & 10,597 & 1,659 & 4,862 & 6,794 & 108 & 36,068 \\
1964 & 3,657 & 9,990 & 1,192 & 4,306 & 5,040 & 74 & 31,096 \\
1965 & 3,326 & 8,960 & 1,059 & 3,461 & 4,840 & 61 & 30,678 \\
1966 & 2,880 & 7,837 & 978 & 2,845 & 4,354 & 49 & 29,011 \\
1967 & 2,819 & 7,523 & 1,271 & 2,384 & 4,242 & 44 & 25,682 \\
1968 & 2,858 & 7,402 & 977 & 2,082 & 4,475 & 40 & 24,247 \\
1969 & 2,804 & 6,711 & 1,283 & 1,910 & 4,072 & 30 & 23,208 \\
1970 & 2,917 & 6,227 & 598 & 1,393 & 3,875 & 24 & 21,740 \\
1971 & 2,030 & 5,153 & 408 & 711 & 2,856 & 15 & 18,608 \\
1972 & 1,588 & 4,611 & 477 & 550 & 2,796 & 13 & 16,087 \\
1973 & 1,723 & 4,415 & 221 & 430 & 2,528 & 10 & 14,529
\end{tabular}


Table 9

Deliveries of Hard Coal as Allowances and to Small-Scale Consumers $(1,000+)$

\begin{tabular}{|c|c|c|c|c|c|c|c|c|}
\hline & & (Fed. Rep.) & France & Italy & Netherlands & Belgium & Lux. & UK \\
\hline & 1960 & 6,515 & 9,814 & 1,441 & 3,376 & 5,381 & 98 & 42,506 \\
\hline & 1961 & 6,261 & 9,923 & 1,522 & 3,397 & 5,585 & 93 & 40,760 \\
\hline & 1962 & 6,627 & 10,526 & 1,481 & 4,072 & 6,122 & 96 & 40,283 \\
\hline & 1963 & 7,567 & 11,798 & 1,668 & 4,942 & 7,262 & 108 & 40,715 \\
\hline & 1964 & 5,438 & 11,068 & 1,200 & 4,383 & 5,490 & 74 & 35,498 \\
\hline & 1965 & 5,000 & 9,965 & 1,068 & 3,565 & 5,284 & 61 & 34,908 \\
\hline$\underline{N}$ & 1966 & 4,368 & 8,721 & 982 & 2,957 & 4,759 & 49 & 32,915 \\
\hline & 1967 & 4,143 & 8,320 & 1,272 & 2,483 & 4,632 & 44 & 29,282 \\
\hline & 1968 & 4,062 & 8,127 & 977 & 2,167 & 4,840 & 40 & 27,538 \\
\hline & 1969 & 3,834 & 7,316 & 1,283 & 1,981 & 4,412 & 30 & 26,213 \\
\hline & 1970 & 3,803 & 6,656 & 598 & 1,450 & 4,162 & 24 & 24,492 \\
\hline & 1971 & 2,757 & 5,509 & 408 & 760 & 3,094 & 15 & 21,117 \\
\hline . & 1972 & 2,212 & 4,926 & 477 & 587 & 3,006 & 13 & 18,302 \\
\hline
\end{tabular}


Table 10

Deliveries of Coke as Allowances and to Small-Scale Consumers $(1,000 \mathrm{t})$ Germany

\begin{tabular}{lccccccc} 
& (Fed. Rep.) & Frarice & Italy & Netherlands & Belgium & Lux. & UK \\
\hline 1960 & 6,971 & 1,561 & 899 & 981 & 254 & 25 & 1,331 \\
1961 & 6,516 & 1,476 & 786 & 894 & 238 & 26 & 1,448 \\
1962 & 7,180 & 1,831 & 940 & 1,032 & 281 & 32 & 1,721 \\
1963 & 8,322 & 2,788 & 1,520 & 1,017 & 394 & 41 & 2,077 \\
1964 & 6,980 & 1,425 & 1,274 & 602 & 284 & 28 & 2,332 \\
1965 & 7,200 & 1,480 & 1,372 & 552 & 289 & 28 & 2,394 \\
1966 & 6,723 & 1,282 & 1,301 & 388 & 236 & 25 & 2,720 \\
1967 & 6,472 & 1,113 & 1,160 & 283 & 198 & 21 & 3,097 \\
1968 & 6,908 & 1,051 & 1,040 & 222 & 201 & 20 & 3,666 \\
1969 & 6,246 & 1,069 & 973 & 128 & 172 & 17 & 3,134 \\
1970 & 5,353 & 842 & 884 & 42 & 121 & 12 & 3,907 \\
1971 & 3,675 & 560 & 529 & 18 & 80 & 7 & 3,670 \\
1972 & 3,138 & 480 & 410 & 12 & 68 & 7 & 3,341
\end{tabular}


The quite drastic falling-off of supplies of solid fuel to households and small-scale users is clearly apparent. Our attention is drawn to the high consumption of hard coal by small-scale consumers in Great Britain, which has persisted up to the most recent times. For the moment, the 1973/74 oil crisis has halted the trend in domestic heating towards conversion from coal to other fuels. At the same time, it is probably safe to predict that, in the long-run, those fuels which are more compatible with the protection of the environment, notably gas and electricity, will make further advances if for no other purpose than that of reducing environmental pollution. In addition, we should expect long-distance heating systems to acquire greater importance. All this argues that facilities for burning waste in the home itself wlll, as a general tendency, become even more limited than at present, and this applies in particular to urban areas. This also implies a further increase in the calorific value of waste, although the rate of increase may be slower.

This increase in calorific value is a factor vital to the development of inclnerating plants. When most incinerating plants were built in the second half of the sixties, the planners applied calorific values which have long since become unrealistic. A few examples may be given: in DUsseldorf in the early sixties the calorific value of the waste was still around 1,000 to $1,200 \mathrm{kcal} / \mathrm{kg}$. As early as $1970 \mathrm{it}$ reached an average value of $1,638 \mathrm{kcal}$ and in 1972 achieved its peak value of $1,758 \mathrm{kcal}$. Owing to the attractive prices paid for waste paper, from mid 1973 onwards a larger amount of waste paper was fed back into the waste paper market and the calorific value of the waste fell back to an average figure of 1,687 kcal. In 1974 it fell even further to $1,587 \mathrm{kcal} / \mathrm{kg}$. Obviously, the conscious economizing on packing materials in the wake of the oil crisis has played its part in this. Since autumn, 1974, the market for waste paper has dried up and the replacement of coal fires by other sources of energy has once again gathered a certain amount of momentum after the transitory period of stagnation. This leads one to the conclusion that in 1975 the calorific value will rise once more and that the figure of $2,000 \mathrm{kcal}$ envisaged for cities should be reached in the next few years.

The information from Dusseldorf is supplemented by data originating from stuttgart. The waste incineration plant there was put into operation in 1965 and the waste burnt at that time had an average calorific value of $1,300 \mathrm{kcal}$. The calorific value reached a temporary maximum of $1,900 \mathrm{kcal} / \mathrm{kg}$ in 1973 and then, following the general pattern, it fell again somewhat. 
Since that time the value has started to rise again in Stuttgart as well. Also from Stuttgart we have interesting data about the connection between ash content and the calorific value of the waste. The increasing calorific value as a function of the falling ash content is clearly illustrated by the fact that in the mid-sixties the ash content in winter was still around 60 per cent and that this has since fallen to 35 per cent owing to the increasing prevalence of gas and oil heating and the use of storage heaters.

Changes in calorific value are of the greatest possible importance in the planning and construction of waste incinerating plants. A plant must be designed right from the storage area, through the incineration chambers and boiler units to the flue gas cleaning equipment on the basis of a given throughput per unit of time. A given calorific value per unit of quantity must be assumed for planning purposes. If the calorific value increases by 35 to 40 per cent, as an easy calculation will show to be the case in the examples cited, then the quantity of waste which can be put through the plant every hour must be reduced by a like amount. Say, for instance, that an inclnerating plant has been designed for a throughput of 40 tonnes of waste per hour with a calorific value of 1,300. If the calorific value is raised to $1,900 \mathrm{kcal}$, it is mathematically necessary to reduce the throughp't to 27.4 tonnes per hour in order to keep constant the thermal flow for which the plant was designed. In practice, values differ somewhat from those calculated mathematically since, to a certain extent depending on the construction of the plant, adaptations are possible. All the same, the calculation, which in a number of towns has tended to reflect the actual state of affairs, demonstrates the difficulty in the light of these imponderables of forecasting the performance and cost of waste incinerating plants. 


\section{A tentative summing up}

In order to determine the calorific value of the waste generated by homes and small businesses a number of hypotheses are unavoidable:

1) As in table 11, the incidence of waste must be based on known average figures.

2) Within specifled upper and lower limits an increase must be allowed for during the period up to 1985 .

3) We must turn our attention to that fraction of the waste which it would be feasible to use for the production of energy, whatever form this took. It is inherent in the matter that this fraction is the subject of much argument. Here, too, upper and lower limits should be set which bear some relation to reality.

4) We must then attempt to convert this fraction, and the absolute quantities derived from it, into terms of calorific value. Here, again, it is impossible to lay down a specific figure. Technical literature on the subject treats with the utmost caution the question of how the calorific value will change over the next ten years. The level of American figures exceeding 3,000 $\mathrm{kcal} / \mathrm{kg}$ would seem to be inapplicable to the European context. For the time being it would probably be more correct to take a figure of $2,500 \mathrm{kcal}$ as the maximum. 
Table Ila

The Incidence of Waste in Common Market Countries

Assuming $227 \mathrm{~kg}$ per head per year

$(1,000 \mathrm{t})$

Germany (Fed. Rep.)

France

Italy

Netherlands

Belgi um

Luxembourg

Great Britain

Ireland

Denmark
1975

\begin{tabular}{rrrr} 
& \multicolumn{1}{c}{$A$} & $B$ & \multicolumn{1}{c}{$C$} \\
\cline { 3 - 4 } 13,999 & 16,246 & 18,828 & 22,803 \\
11,745 & 13,631 & 15,796 & 19,131 \\
12,335 & 14,315 & 16,590 & 20,092 \\
3,026 & 3,512 & 4,070 & 4,929 \\
2,204 & 2,558 & 2,964 & 3,590 \\
79 & 92 & 107 & 129 \\
12,664 & 14,697 & 17,032 & 20,628 \\
683 & 793 & 919 & 1,113 \\
1,135 & 1,317 & 1,526 & 1,849
\end{tabular}

A: assuming an annual growth rate of 1.5 per cent

$B$ : assuming an annual growth rate of 3.0 per cent

$C$ : assuming an annual growth rate of 5.0 per cent

To some specialist writers on the subject the annual figure of $227 \mathrm{~kg}$ on average per head of the population may seem too low. As one is constantly faced with the extrapolation of values determined on a regional basis, the average incidence of waste per head will always be a subject for debate. In Table llb we have set out the figures calculated mathematically on the assumption of an average $300 \mathrm{~kg}$ of waste per head per year.

Table $11 b$

The Incidence of Waste in Common Market Countries

Assuming $300 \mathrm{~kg}$ per head per year

$(1,000 t)$

1975

1985

A B

C

Germany (Fed. Rep.)

18,501

21,422

24,863

30,136

France

15,522

17,793

20,860

25,284

Italy

16,302

18,876

21,908

26,554

Netherlands

3,999

4,630

5,374

6,514

Belgium

2,913

3,373

3,915

4,745

Luxemburg

104

120

140

169 
Table llb continuation:

1985

\section{Great Britain}

Ireland

Denmark

$\begin{array}{r}16,737 \\ 902 \\ 1,500 \\ \hline 76,480\end{array}$

\begin{tabular}{crr}
$\mathrm{A}$ & \multicolumn{1}{c}{$\mathrm{B}$} & \multicolumn{1}{c}{$\mathrm{C}$} \\
\hline 19,379 & 22,493 & 27,263 \\
1,044 & 1,212 & 1,469 \\
1,737 & 2.016 & 2,443 \\
\hline 88,554 & 102,781 & 124,577
\end{tabular}

\begin{abstract}
A: assuming an annual growth rate of 1.5 per cent
$B$ : assuming an annual growth rate of 3.0 per cent

C: assuming an annual growth rate of 5.0 per cent
\end{abstract}

The hypothetical generation of waste has been calculated up to 1985 . We have taken as our basis for (A) an average annual growth rate of 1.5 per cent, for (B) a growth rate of 3 per cent and, finally, for (C) a rate of 5 per cent.

These quantities can be achieved in theory only. They would require the domestic waste generated by every member of the community to be collected and utilized. In practice, this state of affairs can never be brought about. We must start from the assumption that the collection of waste and its practical utilization will increase in the same measure as the density of population and the growth of concentrated urban centres. A more rural social structure has the opposite effect and operates against a high level of waste collection for incineration, firstly, because the distances to centralized incinerating plants are too great and, secondly, because the making of compost is a more practical proposition in farming areas. If the energy consumed in transporting waste to the incinerating plant is greater than the energy it produces when the best technology is applied then economically speaking the absurd situation occurs where, in order to generate energy, more energy is consumed than is gained. Later in this study we shall have to concern ourselves with this factor as one of the criteria which determine the feasibility of producing energy from waste.

We must first of all attempt to determine the theoretical extent to which waste can be collected for the purpose of incineration. In several countries records concerning the amounts of waste collected by the disposal services are far from adequate. In the most densely populated countries we can assume a high level of waste collection, and the Federal Republic of 
Germany may be cited as an example in this connection '). According to the report mentioned in the footnote below, the proportion of households in Nordrhein-Westfalen which are served by a refuse disposal service for domestic waste rises consistently from 78 per cent in communities of 2,000 Inhabitants or under to higher figures in proportion to the size of the community. In those with more than 100,000 inhabitants the figure reaches 97. I per cent. The authors of the Report on the Environment believe that these figures may be regarded as typical.

It may be assumed that the collection of waste will be considerably extended in the next few years even in those areas where, at present, it may be considered inadequate. Although the method of disposing of waste can only be selected on a case to case basis in the light of all the relevant factors, it is nonetheless possible - with the necessary reservations to attempt to obtain approximate figures for the individual member countries of the community. We have to find a factor which takes account of vital parameters relating to the feasibility of collecting and burning the waste. On the one hand the density of population must enter into the calculation and, on the other, the proportion of the total area of the country in question which is devoted to farming. In this connection use has been made of the following basic data which is shown in Table 12 .

Table 12

Size of population and proportion of country devoted to agriculture in EEC Member States

\begin{tabular}{|c|c|c|c|}
\hline $\begin{array}{l}\text { Density of } \\
\text { population } \\
\text { inhabitants } / \mathrm{km}^{2} \text { ) }\end{array}$ & $\begin{array}{l}\text { Area used } \\
\text { for } \\
\text { agriculture } \\
\left(1,000 \mathrm{~km}^{2}\right)\end{array}$ & $\begin{array}{l}\text { Total } \\
\text { area } \\
\left(1,000 \mathrm{~km}^{2}\right)\end{array}$ & $\begin{array}{l}\text { Proportion } \\
\text { of land } \\
\text { used for } \\
\text { agriculture }\end{array}$ \\
\hline
\end{tabular}

$\begin{array}{lrrrr} & & 13,429 & 24,314 & 0.552 \\ \text { France } & 247 & 33,035 & 54,703 & 0.604 \\ \text { Italy } & 179 & 17,649 & 29,404 & 0.600 \\ \text { Netherlands } & 323 & 2,128 & 3,368 & 0.632 \\ \text { Belgi um } & 317 & 1,586 & 3,051 & 0.520 \\ \text { Luxemburg } & 132 & 135 & 258 & 0.523 \\ \text { Great Britain } & 228 & 18,831 & 24,092 & 0.782 \\ \text { Ireland } & 42 & 4,794 & 6,889 & 0.696 \\ \text { Denmark } & 115 & 2,951 & 4,237 & 0.696 \\ \end{array}$

1) 1974 Report of the Expert Commission on Environmental Questions 
If we relate the population density to the ratio of agricultural land to total area, we arrive at the following equation:

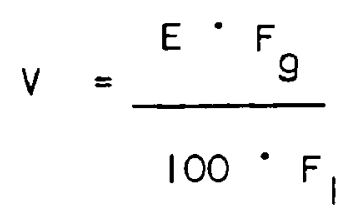

where:

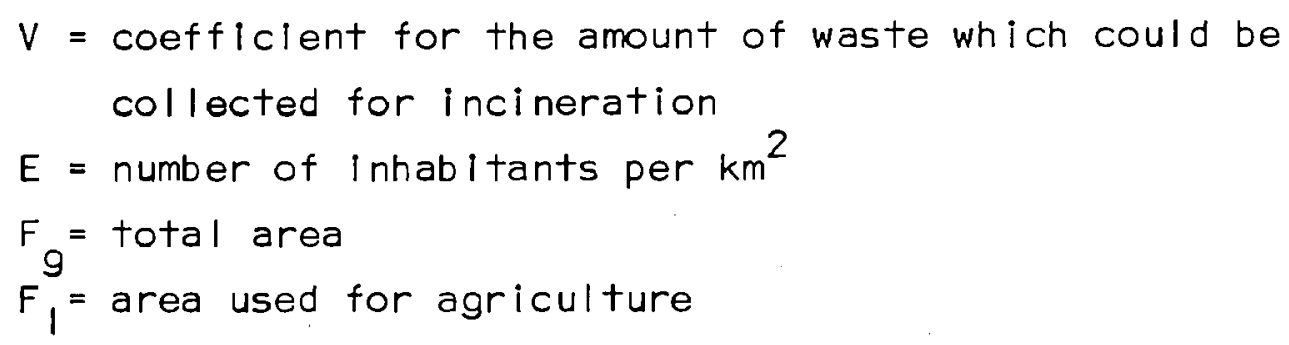

On this basis, the coefficients for the individual member states can be calculated as in table 13:

Table 13

\section{Coefficients of amount of waste collectable for incineration}

$\begin{array}{ll}\text { Germany (Fed. Rep.) } & 0.4474 \\ \text { France } & 0.1156 \quad \text { (corrected to 0.3755) } \\ \text { Italy } & 0.2983 \\ \text { Netherlands } & 0.5110 \\ \text { Belglum } & 0.6096 \\ \text { Luxemburg } & 0.2523 \\ \text { Great Britain } & 0.2915 \\ \text { Ireland } & 0.0603 \\ \text { Denmark } & 0.1652 \text { (corrected to 0.3755) }\end{array}$

In the case of Denmark and France some correction is called for, since in both countries a notably large proportion of the population is concentrated in the capital citles and a few other large towns. In Denmark 27 per cent of the population live in Copenhagen alone, and taken together with Aarhus, Odense and Aalborg-Norresundby the figure is close on 42 per cent. The dominant role of the Paris region is well-known. If the coefficient for both countries is made to equal the average value for Germany, Italy, the 
Netherlands and Great Britain the figure is likely to be closer to the truth. with the help of these coefficients the figures given earlier for the incidence of waste in the countries of the Community can be converted into estimates of those quantities of waste which, according to mathematical prediction, could probably be collected for incineration (or pyrolysis). We assume here that 90 per cent of the total quantity of waste can be collected. This proportion may seem high, but we have assumed that the removal of domestic waste will undergo a marked improvement in all countries in the next few years.

Table 14

Waste Avallable for Incineration in the Countries of the Common Market (in thousands of tonnes)

1) Assuming $227 \mathrm{~kg}$ per head per year

1975

1985

A B

C

\begin{tabular}{lrr} 
Germany (Fed. Rep.) & 5,637 & 6,542 \\
France & 3,969 & 4,607 \\
Italy & 3,312 & 3,843 \\
Netherlands & 1,392 & 1,615 \\
Belgium & 1,209 & 1,403 \\
Luxemburg & 18 & 21 \\
Great Britain & 3,323 & 3,856 \\
Ireland & 37 & 43 \\
Denmark & 384 & 445 \\
\multicolumn{2}{c}{ 2) Assuming $300 \mathrm{~kg}$ per head per year }
\end{tabular}

1975

1985

A B

C

Germany

7,450

8,627

10,012

12,136

Italy

5,245

6,074

7,050

8,545

Netherlands

4,377

5,068

5,883

7,130

1,839

2,129

2,472

2,996 
(Table 14 continued)

1975

1985

A B C

Belgium

1,598

1,850

2,148

2,603

Luxemburg

24

27

32

38

Great Britain

4,392

5,085

5,902

7,154

Irel and

48

57

66

80

Denmark

The Community

507

587

681

826

$25,480 \quad 29,504 \quad 34,246 \quad 41,508$

For explanation of A, B, C see page 26.

The efforts needed if the estimated figures for 1985 are really to be achieved can be seen from some available data. For instance, the data relating to the proportion of waste disposed of by incineration in the Federal Republic of Germany put the figure between 17 and 25 per cent. Given an amount of 13 to $14 \mathrm{mill}$ ion tonnes of domestic waste, this means a quantity of 2.2 to 3.5 mlllion tonnes to be incinerated. In the 1974 Report on the Environment for the Federal Republic of Germany a survey of incinerating plants in the Federal Republic is quoted from Report on waste Incineration (Der stydtetag, 5/1973). According to this survey, the hourly waste throughput of all the installed furnace capacity should be put at 550 tonnes. Of course, this does not take account of the fact that, as a result of the much increased calorific value of the waste since the equipment was put into operation, the throughput capacity of a number of these furnaces has been reduced. If these incinerating plants were operated throughout the year on a three-shift basis, as happens in large plants with energy recuperation (though with the occaslonal temporary shutdown of individual boilers), then we would arrive at a theoretical maximum throughput capacity of $4.87 \mathrm{mill}$ ion tonnes per annum. It does not seem unrealistic to deduct 20 per cent from this figure to take account of breakdowns and the intermittent mode of operation of the small units. This gives a yearly throughput figure of 3.9 million tonnes, and the capacity is therefore not very far from the estimated quantity to be incinerated.

A further example is provided by the Netherlands. According to a 1974 government report on the disposal of waste, the annual quantity of 
domestic waste generated in the Netherlands is put at 3.9 million tonnes 1 ). fccording to the same report, 25 per cent of this quaritity or 975,000 tonnes, is burnt. Here, too, considerable efforts would therefore be necessary to reach the tonnages whlch we have predicted mathematically to be available for incineration or pyrolysis.

1) The divergence from the estimated figure arrived at by us is due to the average per caplta incidence used as a basis. It has no relevance to the assessment of trends. 


\section{Waste as a source of energy}

In endeavouring to convert into energy yield the quantity of waste calculated mathematically as being available for incineration, a reservation must be stated at the outset: not all incineration plants are suitable for the recovery of energy. In small plants the destruction of the waste is the prime objective. The construction of boiler plants linked to longdistance heatlng systems or electricity generating stations is only worthwhile if the waste is supplied and incinerated in an urban context (i.e. in urban areas with 100,000, or in view of continually rising capital costs say, rather, 500,000 inhabitants). In the technical section of this study it will, of course, be necessary to draw attention to the fact that the (rightly) more stringent demands for flue gas cleaning and dust removal will have a disproportionate effect in raising the unit costs of small incinerating plants in particular. In large plants, the utilization of the temperature drop from $850^{\circ}-1,100^{\circ}$ in the incineration chamber to $250^{\circ}$ at the electrofilters does at least contribute to meeting the cost of the cleaning operation.

Particular interest attaches to a study by $w$. KBrbel' ${ }^{\prime}$ relating to the factors and calculations governing the use of waste as fuel for energy production. K\&rbel has the following points to make: 'According to the

1) 'MUII als Brennstoff' (Waste as Fuel) by Wilhelm Korbel. Energie und Technik, No. 2/1974 
Feceral Bureau of Statistics there are in the Federal Republic of Germany 22.9 million households with an average of 2.7 members. From numerous surveys it is known that the annual per capita incidence of waste is around 350 to $400 \mathrm{~kg}$. If we base ourselves on the lower figure, the quantity of waste in a year amounts to $21.65 \mathrm{million}$ tonnes. The average calorific value in the Federal Republic of Germany is at present around 1,800 kcal/kg. That is equivalent to a present total gross figure of $38.9 \mathrm{mill}$ ion Gcal per annum of heat energy.'

'According to data provided by the electricity supply industry, the amount of electricity consumed annually in the home is $48.6 \mathrm{mill}$ ion MWh.'

'After allowing for losses, about $6.53 \mathrm{million}$ MWh can be generated from the heat energy resulting from waste incineration. That is about 13.4 per cent.'

'Where space heating requirements are concerned, the figures are as follows: '

'The space heating required for all the households in the Federal Repub|ic of Germany amounts to 274.0 million Gcal per annum. After allowing for all losses, $20.6 \mathrm{mill}$ ion Gcal per annum, that is about 7.5 per cent of total consumption could be produced from waste.'

If this is expressed in terms of the cost of fuel, then, taking tiday's oil prices as a basis, this quantity of waste has a value of 340 million DM per annum when used for generating electricity and 700 million DM per annum when converted into long-distance heating.'

We shall not discuss hare whether the per capita incidence of waste has not been set much too high. Much more interesting is the calculation for converting this into heat, electrical energy and oil equivalent (based on the price of oil). This is an assessment which should certainly be taken up, as indeed mineral oil equivalents for the quantities of waste occurring in Europe as given in the study on Material Flows in the Post Consumer Waste Stream of the European Economic Community l). As has already een pointed out, it is only necessary, when making such calculations, to base oneself on the quantity of waste which can actually be collected.

1) Sentre de Planification des Ressources, November 1974 Fublished as part of this series by Graham \& Trotman 
The first thing is to determine the factors which may be accepted as relevant to a realistic conversion of waste into terms of energy. We have concerned ourselves initially with converting the amounts of waste calculated to be avallable for collection into calorlfic values and, in so doing, we have made two alternative assumptions:

1) An average Incldence of waste of $227 \mathrm{~kg}$ per head per year, as mentioned at the beginning, and

2) The higher annual per capita incidence of $300 \mathrm{~kg}$.

Alongside the mathematically calculated value for 1975 is shown in each case a value for 1985 based on the highest assumed annual rate of growth of 5 per cent 1). These two basic figures have been converted into terms of heat energy at the rates of $1,600,1,800,2,500$ and $3,000 \mathrm{kcal} / \mathrm{kg}$. It is difficult to predict at what calorific value the waste generated in the various countries of the Community will stabilize in the long term. This is why large margins of variation must be allowed for in the estimates. Attention has already been drawn to the fact that, in all probability, the hlgh calorific values of 3,000 to $3,500 \mathrm{kcal} / \mathrm{kg}$ experienced in the U.S.A. will not be reached in the Community.

1) To many observers famlliar with higher figures this rate of growth may seem very low. However, together with a gross national product which is falling well short of earlier expectations in western industrlalized nations we shall also have to accept a slowing down in the generation of waste. It may indeed be supposed that the deceleration in economic growth will be reflected in accentuated form in the drop in waste generation. 
Conversion of Probably Available Quantities of Waste Into Terms of Heat Energy on the Basis of Different Calorific Values

$$
(\ln 1,000 \mathrm{Gcal})
$$

Assuming $227 \mathrm{~kg}$ of waste per head per year ${ }^{1)}$

Calorific Value $\mathrm{H}_{u}$ (kcal/kg) $1,600 \quad 1,800 \quad 3,500 \quad 3,000$

\begin{tabular}{|c|c|c|c|c|c|}
\hline \multirow[t]{2}{*}{ Germany (Fed. Rep.) } & 1975 & 9,020 & 10,150 & 14,090 & 16,910 \\
\hline & 1985 & 14,690 & 16,530 & 22,960 & 27,550 \\
\hline \multirow[t]{2}{*}{ France } & 1975 & 6,350 & 7,140 & 9,920 & 11,910 \\
\hline & 1985 & 10,340 & 11,640 & 16,170 & 19,400 \\
\hline \multirow[t]{2}{*}{ Italy } & 1975 & 5,300 & 5,960 & 8,280 & 9,940 \\
\hline & 1985 & 8,630 & 9,710 & 13,490 & 16,180 \\
\hline \multirow[t]{2}{*}{ Nether lands } & 1975 & 2,230 & 2,510 & 3,480 & 4,180 \\
\hline & 1985 & 3,630 & 4,080 & 5,670 & 6,800 \\
\hline \multirow[t]{2}{*}{ Belgium } & 1975 & 1,930 & 2,180 & 3,020 & 3,630 \\
\hline & 1985 & 3,150 & 3,550 & 4,930 & 5,910 \\
\hline \multirow[t]{2}{*}{ Luxemburg } & 1975 & 29 & 32 & 45 & 54 \\
\hline & 1985 & 46 & 52 & 73 & 87 \\
\hline \multirow[t]{2}{*}{ Great Britain } & 1975 & 5,317 & 5,981 & 8,308 & 9,969 \\
\hline & 1985 & 8,659 & 9,742 & 13,530 & 16,236 \\
\hline \multirow[t]{2}{*}{ Ireland } & 1975 & 59 & 67 & 93 & 111 \\
\hline & 1985 & 96 & 108 & 150 & 180 \\
\hline \multirow[t]{2}{*}{ Denmark } & 1975 & 614 & 691 & 960 & 1,150 \\
\hline & 1985 & 1,000 & 1,125 & 1,563 & 1,875 \\
\hline
\end{tabular}

1) The figures for 1985 assume the highest annual growth rate of 5 per cent. 
Conversion of Probably Available Quantities of Waste into Terms of Heat Energy on the Basls of Different Calorific Values

(in I, O00 Gcal)

Assuming $300 \mathrm{~kg}$ of waste per head per year ${ }^{\prime \prime}$

\begin{tabular}{|c|c|c|c|c|c|}
\hline Calorific Value $\mathrm{H}_{\mathrm{u}}$ & $\mathrm{kcal} / \mathrm{k}$ & 1,600 & 1,800 & 2,500 & 3,000 \\
\hline \multirow[t]{2}{*}{ Germany (Fed. Rep.) } & 1975 & 11,920 & 13,410 & 18,625 & 22,350 \\
\hline & 1985 & 19,418 & 21,845 & 30,340 & 36,408 \\
\hline \multirow[t]{2}{*}{ France } & 1975 & 8,392 & 9,441 & 13,113 & 15,735 \\
\hline & 1985 & 13,672 & 15,381 & 21,363 & 25,635 \\
\hline \multirow[t]{2}{*}{ Italy } & 1975 & 7,003 & 7,879 & 10,943 & 13,131 \\
\hline & 1985 & 11,408 & 12,834 & 17,825 & 21,390 \\
\hline \multirow[t]{2}{*}{ Netherlands } & 1975 & 2,942 & 3,310 & 4,598 & 5,517 \\
\hline & 1985 & 4,794 & 5,393 & 7,490 & 8,988 \\
\hline \multirow[t]{2}{*}{ Belgium } & 1975 & 2,557 & 2,876 & 3,995 & 4,794 \\
\hline & 1985 & 4,165 & 4,685 & 6,508 & 7,809 \\
\hline \multirow[t]{2}{*}{ Luxemburg } & 1975 & 38 & 43 & 60 & 72 \\
\hline & 1985 & 61 & 68 & 95 & 114 \\
\hline \multirow[t]{2}{*}{ Great Britain } & 1975 & 7,027 & 7,906 & 10,980 & 13,176 \\
\hline & 1985 & 11,446 & 12,877 & 17,885 & 21,462 \\
\hline \multirow[t]{2}{*}{ Ireland } & 1975 & 77 & 86 & 120 & 144 \\
\hline & 1985 & 128 & 144 & 200 & 240 \\
\hline \multirow[t]{2}{*}{ Denmarrk } & 1975 & 811 & 913 & 1,268 & 1,521 \\
\hline & 1985 & 1,322 & 1,487 & 2,065 & 2,478 \\
\hline
\end{tabular}

1) The figures for 1985 assume the highest annual growth rate of 5 per.cent. 
We shall now convert the mathematically determined heat energy from the available waste, corresponding to specific calorific values $\left(H_{u}\right)$ between 1,600 and $3,000 \mathrm{kcal} / \mathrm{kg}$, into both electrical energy and mineral oil equivalents.

In converting heat into electrical energy we start with the following equation, which assumes 100 per cent efficiency:

$$
860 \mathrm{kcal} \bumpeq 1 \mathrm{kWh}
$$

Of course, 100 per cent efficlency is never achieved. By comparison with homogeneous and more easily controlled fuels such as lignite, hard coal, oil and gas, additional allowances ought to be made when burning waste since its highly variable calorific value coupled with the equally erratic quality of the waste gases make it very difficult to operate a power station continuously so as to produce the optimum output. Here, however, we shall disregard such allowances. To find out the specific heat consumption we have used the table given in the Babcock-Handbuch Dampf (Babcock Steam Handbook)' ') which not only shows the amount of heat energy required per kWh of electricity generated as a function of the power station output, but also gives the specific quantity of steam in $\mathrm{kg} / \mathrm{kWh}$.

Table 16

Efficiency factors of power stations

\begin{tabular}{cccc}
\hline $\begin{array}{c}\text { Power Station } \\
\text { Output } \\
M W\end{array}$ & $\begin{array}{c}\text { Spec. Heat } \\
\text { Consumption } \\
\mathrm{kcal} / \mathrm{kWh}\end{array}$ & $\begin{array}{c}\text { Spec. Steam } \\
\text { Requirement } \\
\mathrm{kg} / \mathrm{kWh}\end{array}$ & $\begin{array}{c}\text { Thermal } \\
\text { Efficiency } \\
\text { Per cent }\end{array}$ \\
\hline 60 & 2,590 & 3.86 & 33.2 \\
100 & 2,410 & 3.60 & 35.7 \\
150 & 2,320 & 3.46 & 37.1 \\
300 & 2,230 & 3.33 & 38.6 \\
600 & 2,185 & 3.26 & 39.4 \\
\hline
\end{tabular}

1) 4th edn. 1965. Vulkan-Verlag Dr. W. Classen, Essen 
Power stations with an output of $60 \mathrm{MW}$ are rare nowadays. On the other hand, power station units generating $600 \mathrm{MW}$ and over are certainly not suitable for a fuel as awkward as waste. The larger they are, the more likely is the use of fossil fuels (lignite, hard coal, oil or gas) or nuclear energy to generate the base and medium load. We shall come closest to reality if we assume a $150 \mathrm{MW}$ power station output when we come to convert the heat energy of the waste. That means a thermal efficiency of 37.1 per cent, and an energy consumption of $2,320 \mathrm{kcal} / \mathrm{kWh}$.

In calculating the potential amount of electricity which could be generated from the avallable resources of waste, we have assumed at the outset an average annual per capita incidence of waste of $300 \mathrm{~kg}$ with a calorific value of $2,500 \mathrm{kcal} / \mathrm{kg}$. These figures are probably at the upper end of a realistic scale. At the same time, for 1985 we have assumed the maximum annual rate of growth of 5 per cent.

Table 17

Conversion of Thermal Energy into Electricity

(GWh)

Germany (Fed. Rep.)

\begin{tabular}{rr}
$1974 / 75$ & $1985^{1)}$ \\
\hline 8,028 & 13,078 \\
5,652 & 9,208 \\
4,717 & 7,683 \\
1,982 & 3,228 \\
1,722 & 2,805 \\
26 & 41 \\
4,733 & 7,709 \\
52 & 86 \\
547 & 890 \\
\hline
\end{tabular}

27,459

44,728

1) With an annual rate of growth of 6 per cent 
Table 18

Electricity Generation in the Community

(GWh)

\begin{tabular}{lrr} 
& 1974 & $1985^{1}$ \\
\cline { 2 - 3 } Germany (Fed. Rep.) & 312,550 & 593,314 \\
France & 188,300 & 357,450 \\
Italy & 149,500 & 287,796 \\
Netherlands & 55,210 & 104,805 \\
Belgium & 42,799 & 81,245 \\
Luxemburg & 2,078 & 3,945 \\
Great Britain & 273,594 & 519,363 \\
Ireland & 7,885 & 14,968 \\
Denmark & 18,756 & 35,605 \\
& & $1,994,491$
\end{tabular}

Up to the present time it has been assumed that the generation of electricity doubles every ten years, which is equivalent to an average arnual growth rate of 7.2 per cent. In most recent times expectations have been lowered in consequence of the changes taking place in the structure of the energy market. It would certainly be overpessimistic to reduce the articipated annual growth rate to 4 per cent, but a drop to 6 per cent per annum is clearly a real possibility.

Comparison of the figures given for electricity generation in Community countries (actual figures for 1974, estimates for 1985) with the mathematically feasible quantity (still far short of achievement) which could be generated from domestic waste reveals the latter's minor significance when measured against the overall figures. Of course, a positive argument can be deduced from this which should not be overlooked: if the amount of energy which can be obtained from waste is small by comparison

1) With an annual rate of growth of 6 per cent 
with overall production (and therefore requirements) then, assuming that its collection and Inclneration were to prove very expensive, it would be easier to argue for a mixed method of costing to cover both 'power from waste' and that produced more economically by other means.

At this point it may be of interest to consider the relationship between the 'power from waste' and the actual overall figures for electricity production.

$$
\text { Table } 19
$$

Theoretically Possible Production of Electricity from Domestic Waste In Relation to Total Electricity Generated

as a percentage

\begin{tabular}{lcc} 
& 1974 & $1985^{1}$ \\
\cline { 2 - 3 } Germany (Fed. Rep.) & 2.56 & 2.20 \\
France & 3.00 & 2.57 \\
Italy & 3.15 & 2.70 \\
Netherlands & 3.58 & 3.08 \\
Belgium & 4.02 & 3.45 \\
Luxemburg & 1.25 & 1.03 \\
Great Britain & 1.72 & 1.48 \\
Ireland & 0.65 & 0.57 \\
Denmark & 2.91 & 2.49
\end{tabular}

1) Assuming an annual rate of growth of 6 per cent 


\section{[omestic waste in place of oil?}

Since the use of domestic waste as a source of energy was the subject of particularly lively debate in connection with the difficulties experienced during the oil crisis around the turn of the year in 1973/74, a comparison between the heating capabilities of domestic waste and mineral oil deserves special attention. First of all, it will be appropriate to consider the relative calorific values of the important fuels listed in table 20.

Table 20

Calorific values of various fuels

$\begin{array}{ll}\text { Crude lignite (Rhineland) } & 1,950 \mathrm{kcal} / \mathrm{kg} \\ \text { Hard coal (the Ruhr and Aachen, gas } & \\ \quad \text { and open burning coal) } & 7,200-7,600 \mathrm{kcal} / \mathrm{kg} \\ \text { Natural gas } & 8,000-9,500 \mathrm{kcal} / \mathrm{kg} \\ \text { Fuel Oil } & 9,800-10,000 \mathrm{kcal} / \mathrm{kg}\end{array}$

As a rough gulde, hard coal is assumed to have a calorific value of $7,000 \mathrm{kcal} / \mathrm{kg}$, and fuel oil a value of $10,000 \mathrm{kcal} / \mathrm{kg}$. The short list shows that waste bears comparison with lignite as regards its calorific value, though the comparison breaks down when we consider the mining of lignite (in large-scale, open workings) and its eminent suitability for use in power stations. From the point of view of relative heat values, the greatest difference is that between waste and fuel oil. Looked at purely mathematically, if domestic waste has a calorific value of $2,500 \mathrm{kcal} / \mathrm{kg}$, this means that 
$250 \mathrm{~g}$ of fuel oil will generate as much heat as one kilogram of waste. Depending on the calorific value attributed to the available waste, this can be converted into terms of fuel oil equivalent. In making this conversion we shall content ourselves with the values which have been established at the present time, since we are only concerned to ascertain the relative magnitudes involved.

Table 21

Fuel Oll Equivalent of Waste Theoretically Available for Incineration

(in thousands of tonnes)

Calorific Value

\begin{tabular}{lrrrr} 
of Waste (kcal/kg) & 1,600 & 1,800 & 2,500 & 3,000 \\
\hline Germany (Fed. Rep.) & 1,192 & 1,341 & 1,863 & 2,235 \\
France & 839 & 944 & 1,311 & 1,574 \\
Italy & 700 & 788 & 1,094 & 1,313 \\
Netherlands & 294 & 331 & 460 & 552 \\
Belglum & 256 & 288 & 400 & 479 \\
Luxemburg & 4 & 4 & 6 & 7 \\
Great Britaln & 703 & 791 & 1,098 & 1,318 \\
Ireland & 8 & 9 & 12 & 14 \\
Denmark & 81 & 91 & 127 & 152 \\
& 4,077 & 4,587 & 6,431 & 7,644
\end{tabular}

This means that, even assuming a calorific value of $3,000 \mathrm{kcal} / \mathrm{kg}$, which for the time being anyway can only rarely be reached, and an annual per capita incidence of waste of $300 \mathrm{~kg}$, the quantity of thermal energy which could be obtalned by incinerating the waste would 'replace' 7.64 million tonnes of oil. The significance of this is apparent when we consider the total mineral oll consumption of the nine member countries of the Community in 1974 which amounted to some $530 \mathrm{million}$ tonnes.

This straightforward comparison of quantities does not, of course, provide us with. the decisive criterion to determine whether it is sensible to promote the use of waste to generate heat energy with the object of economizing on other, primarily imported, sources of fuel. But the calculation does make it clear that the idea of using waste as a source of energy in order to give Community countries at least some degree of independence from supplies of imported oil would be completely misconceived. 
Even more important in this connection is the relationship between costs and the energy yield of waste incineration. At first sight, waste is a source of energy which 'costs nothing' since it occurs anyway. It has to be disposed of in any case, and it seems more reasonable to tap the energy which it contains than simply to dump it. However, this argument naturally no longer holds if, when compared with the cost of dumping or composting, additional costs are involved in obtaining the energy and if these additional costs are greater than the gain from the energy produced. From the economic standpoint this would, on balance, be tantamount to wasting energy, and the total expenditure involved in obtaining the energy from the waste could, after deducting credit items for heat, steam and electricity, be expressed in terms of an equivalent amount of imported mineral oil. Reports about the cost of incineration per tonne of waste vary widely. It is not the purpose of the present study to examine incineration costs in any detail. They must be ascertained in each case individually in the I ight of the potential use of scrap, slag, steam and electricity. Since the technical data relating to incinerating plants hardly differ from one country to the next, the costs, calculated in dollars, may certainly be compared with each other. Wages do not play a vital part; it is the capital cost and the energy consumption which are the crucial factors.

Taking net costs, if we assume a scale of 15 to 40 dollars a tonne for incinerating the waste classed as available, then we are underestimating rather than exaggerating the costs involved. By way of illustration, let us mention here a calculation, considered to be objective, whose authors ${ }^{1}$ recommend that the figures established by them in the context of 1970 should be multiplied by a factor of 2.5 to take account of intervening price increases. This would mean that the costs involved in burning each tonne of waste would be between 35.70 and $89.70 \mathrm{DM}$ ( 15.50 and 39.00 dollars at 2.30 DM to the dollarl depending on a number of variables. The figures thus fall within the selected limits.

1) W. Kurbel and A. Oleynik: 'Energieerzeugung bei Abfallverbrennung im Verbund mit Wyrme-Kraftanlagen' ('The Production of Energy by Waste Incineration Linked to Thermal Generating Plant'). Energie Zeitschrift fur praktische Energietechnik, 11/1970 
Table 22

Total Cost of Incinerating Avai lable Quantities of Waste (Assuming an Incldence of $300 \mathrm{~kg}$ per head per year)

(in millions of dollars)

Specific cost of

incineration per

tonne (in dollars)

15

20

25

30

40

Germany (Fed. Rep.)

111.8

149.0

186.3

223.5

298.0

France

78.7

104.9

131.1

157.4

209.8

Italy

65.7

87.5

109.4

131.3

175.1

Netherlands

27.6

36.8

45.9

55.2

73.6

Belgi um

23.9

32.0

40.0

47.9

63.9

Luxemburg

0.36

0.48

0.60

0.72

0.96

Great Britain

65.9

87.8

109.8

131.8

175.7

Ireland

0.72

0.96

1.20

1.44

1.92

Denmark

7.61

10.1

12.7

15.2

20.3

$\begin{array}{lllll}382.3 & 508.7 & 637.0 & 775.9 & 1018.4\end{array}$

In consldering these costs it is proper to ask how much oil could be bought for the same amount of money. We are probably being realistic if we assume an oll price of 11.00 dollars a barrel. This price must then be converted into the price per tonne as the only way to achieve a basis for comparison. It is then necessary to examine the relationship between, on the one hand, the amounts of domestic waste which we have shown in thls study to be the maximum feasible for the production of energy and, on the other, those quantitles of fuel which could be purchased for the equivalent of the same total expenditure. 
Table 23

Total Cost of Waste Incineration in Terms of Mineral Oil Equivalent

(in thousands of tonnes)

Specific cost of incineration per tonne (in dollars) 15 20 25 30 40

\begin{tabular}{lrrrrr}
\hline Germany (Fed. Rep.) & 1,372 & 1,828 & 2,285 & 2,742 & 3,656 \\
France & 965 & 1,287 & 1,608 & 1,931 & 2,574 \\
Italy & 806 & 1,073 & 1,342 & 1,611 & 2,148 \\
Netherlands & 339 & 451 & 563 & 677 & 903 \\
Belgi um & 293 & 393 & 491 & 589 & 785 \\
Luxemburg & 5 & 6 & 7 & 9 & 12 \\
Great Britain & 808 & 1,077 & 1,347 & 1,617 & 2,155 \\
Ireland & 9 & 12 & 15 & 18 & 24 \\
Denmark & 93 & 124 & 156 & 186 & 249 \\
& & & & & 12,506
\end{tabular}

If one were to dispense entirely with the production of energy from waste incineration and to devote the money which would thereby be saved exclusively to the purchase of mineral oil at 11 dollars a barrel, then the Community could buy annually between 5 and 12 million tonnes of mineral oil. At the same time we have established that, given the maximum collection of all disposable waste and its optimum utilization for the production of energy, an amount of heat could be generated which, within realistic limits, would be equivalent to 4.6 to $6.4 \mathrm{million}$ tonnes of fuel oil. Put crudely, this means that the cost of waste incineration is far greater than the value of the energy which can be produced thereby. 


\section{Domestic waste no substitute for oil}

The conclusion drawn here should not be regarded as an indictment of waste inclneration. The burning of domestic waste may be necessary for a number of reasons and, in these cases, the fact will have to be accepted that around 40 per cent by weight of the waste input will have to be redisposed of as slag - a figure which is more likely to increase than drop thanks to the growing proportion of glass.

In all Instances where the incineration of waste is unavoidable, and where the quantity throughput is sufficiently large, it is advisable to utillze the energy released by burning the waste. For technical and environmental reasons the temperature in the Incineration chamber must be at least $800^{\circ}$, whereas the elctrofilters can only deal with waste gases up to a maximum of $250^{\circ}$. The equipment required to bring about this temperature drop in the waste gases costs money, and it is therefore reasonable to make use of this heat energy rather than waste it.

All the same, the production of energy cannot, as has been demonstrated above, provide the primary motive for the building of waste incinerating plants. 


\section{The production of energy from sewage sludge}

Sewage sludge presents local authorities with a number of special problems. It can no longer be released, unpurified, into rivers, the selfcleansing capabilities of which are already under extreme pressure in densely populated areas in particular. However, purification in tanks calls for substantial capital expenditure and takes up a lot of space.

The question to be answered here is whether it could be used as a source of energy. Domestic sewage sludge contains about 95 per cent water, the remaining 5 per cent dry matter as a rule being mainly organic matter. When dry, it thus has a relatively high calorific value, which, for the organic matter itself, can be put at $5,000 \mathrm{kcal} / \mathrm{kg}$. This calorific value of the dry matter varies according to the type and the pretreatment of the sludge 1$)$. Digested sludge, i.e. that which has undergone anaerobic biological conversion, has dry matter with the lowest calorific value: 2,000 to $2,500 \mathrm{kcal} / \mathrm{kg}$. On the other hand, primary sludge with 3,000-3,750 kcal, surplus sludge with 3,750 to $4,250 \mathrm{kcal}$ and mixed sludge with 3,000 to $3,250 \mathrm{kcal}$ have much higher calorific values.

1) Dipl.-Ing. W. Schlotmann: 'Klürschlamm, seine Behandlung und Beseitigung speziell durch gemeinsame Mull-Klärschlammverbrennung' ('Sewage sludge, its processing and disposal, with particular reference to combined sludge/waste incineration'), Het Ingenieurblad, 10/1973 
According to the source quoted, a daily quantity of $85 \mathrm{~g}$ of dry matter per head of population is the accepted figure for the mechanical and biological. purification of sewage. This is equivalent to a yearly figure of 31 kg. Given a calorific value of $3,500 \mathrm{kcal}$, this would amount to 108,500 kcal per annum per head of the population. In order to appreciate the orders of magnitude with whlch we are concerned here, these $108.5 \mathrm{Mca} /$ should be vlewed in relation to the per caplta consumption of energy. We give in table 24 examples for 1974:

Table 24

\section{Per capita consumption of energy}

$\begin{array}{ll}\text { Federal Republic of Germany } & 38,780 \text { Mcal } \\ \text { France } & 29,400 \text { Mcal } \\ \text { The Netherlands } & 37,030 \text { Mcal }\end{array}$

In this connection it must be pointed out that the 108.5 Mcal represent a purely theoretical figure, which would only be achieved if all the sewage sludge generated could be collected and used to produce energy. To project this figure to include the entire population would degenerate into nothing more than a game with numbers since, in some countries and depending on the population pattern, part of the sewage does not pass through treatment plants. This is particularly the case where the infrastructure is strongly rural in character.

If this has already made it clear that, in purely theoretical terms, the complete utilization of sewage sludge for energy production would produce a quantity of energy equivalent to only a fraction of one per cent of requirements, attention must also be drawn to the cost of generating energy from this source.

It has been pointed out in the preamble that sewage sludge contains 95 per cent water. The low coagulability characteristic of sewage sludge can be increased by using sedimentation agents. These cause the solids to settle and provide the possibility of getting rid of some of the water. In this manner the water content of the sludge can be reduced to around 70 per cent, but in order to burn the organic matter in the sludge the water must be evaporated off and that means consuming energy. 
Coping with fuels which contain moisture is nothing new. Lignite ccrtains a greater or lesser quantity of water depending on its provenance, and wood contains a certain amount of water. Problems connected with moisture content have also been discussed in relation to waste incineration. All the same, where sewage sludge is concerned, the water content is extremely high.

$1+$ is for this reason that the burning of sewage sludge is not generally accepted as a means of generating energy, even by those who favour the production of energy by waste incineration. This does not rule out the possibility that, in some individual cases, the burning of sludge may be feacible. In congested areas of population it may be advantageous, or even necessary, to reduce sewage sludge to a fraction of its original volume by burning the organic matter which it contains insteac of treating it chemically and mechanically, thickening it in drying beds and then dumping it. cisposing of sewage sludge to farmers meets with partially justified reluctance on their part. Therefore, taking all factors into account including the high cost of the land needed in the most thickly populated areas, incineration may represent a favourable solution. But for the purpose of generating energy, sewage sludge can be ignored. 
PART B

THE TECHNICAL BACKGROUND

In the present study we shall consider the incineration of waste in special detail. This is necessary since, so far, only the incineration of waste has acquired real importance. Where the metallurgical application of waste is concerned, we do not yet have at our disposal any practical criteria which ensure success. The position is similar as regards pyrolysis of waste, though unlike the metallurgical use pyrolysis has already received the backing of a number of official development projects. As a result of this we shall, in the near future, see a whole range of plants testing pyrolysis on a long-term, large-scale basis. This study will accordingly pay greater attention to waste pyrolysis than to its application in the metallurgical field. 


\section{An introduction to waste incineration}

Temperatures up to $1,100^{\circ}$ are needed in order to burn waste. One reason for this is to guarantee the total incineration of all the combustible matter which normally occurs in waste. Secondly, high temperatures are needed to ensure that the burning process will have no troublesome sideeffects and, in particular, that it will be odourless. Before the waste starts to burn, smouldering begins at $250^{\circ}$ to $300^{\circ} \mathrm{C}$. Without the introduction of alr, full carbonization takes place, but if air is introduced then the required incineration occurs.

There are a number of types of process which may be used for incinerating waste. The most important are:

1. Grate firing

2. Inclneration in rotating kilns

3. Incineration in re-flow rotating kilns

These basic processes wlll be considered below. Besides the technical differences which distinguish these types of process, there are of course the subjective factors which make themselves felt in all discussions. We are not, then, solely concerned with the practical experiences of the operators of individual waste incinerating plants but also with links to manufacturers and with the sclentiflc training of the engineers. In theory, no undue importance should attach to the subjective factors in the discussion, but in practice they play a not insignificant role.

As In the majority of other Community countries, it is clearly grate firing whlch predominates at present in the Federal Republic of Germany. 
For this reason, we shall look at this process in particular detail below. As regards the varlous types of process (grate firing, incineration in rotating $k$ lins or re-flow rotating kilns) we shall first of all consider in each case the fundamental principle of the process, and only then shall we look at the varlous special types of construction where these have already acquired practical importance. The degree to which grate firlng dominates the present scene can be III ustrated by the example of the Federal Republlc of Germany. In that country there are at the present time 35 large-scale plants with a total of some 100 incineration units, or furnaces, engaged In the burning of waste. The term 'furnace' is taken to mean the incineration chamber and the boiler unit which subsequently utilizes the heat generated by the incineration process. When speaking of large-scale plants we mean those which fulfil the criterion of having an hourly throughput capaclty of 12 tonnes of waste per furnace. Apart from the large-scale plants, the statistics also mention medium-sized and small plants. 


\section{The various methods of waste incineration 1. GRATE FIRING}

Grate firing is a continuous process and this is a great advantage since the incineration units do not need continually to be recharged and emptled of residues. The continuous method of throughput makes a vital contribution to the economlcs of grate firing. In view of the disproportionate increase in the wages bill, the advantage inherent in the contlnuity of the process will acquire increasing importance. This factor is, for instance, of significance when grate firing is compared with pyrolysis, for which at present no continuous process exists. Practically speaking, the continuous process operates in the following manner. The waste to be burnt is propelled mechanically along a grate which generally slopes downwards slightly. Different technlques of grate firing use different speeds for the varlous sections of the grate. The reason for this is that a part of the waste burns very quickly and the gaps that this causes can then be refilled provided that the process operates in such a way that the speed of the grate decreases as the distance travelled increases. If waste were a fuel of homogeneous structure, this differentlal veloclty would not be necessary as the waste would burn uniformly. In all grate firing processes, a large part of the waste is removed early on as gas and the combustible gases are then burnt during the further course of the process. It is important for incineration that the waste should be uniformly mixed together and charged evenly on to the grate. If this is not done, then phenomena rapidly occur which constitute some of the serious disadvantages of grate firing. 
This may take the form of isolated pockets of incompletely burnt waste or points at which the composition of the waste causes ar excessively high temperature in relation to the average temperature of the combustion chamber. The first phenomenon leads to slag which still contains rotting components that cause trouble on the dumping site, while local overheating causes correspondingly greater plant corrosion.

Insufficient or excessive heating may be caused, for instance, by wide variations in the moisture content of the waste, which has not been mixed with sufficient thoroughness to even this out. All waste contains moisture, but the range of variation is exceptionally wide.

Grate firing is also frequently referred to as 'up-draught' firing because of the direction of the air flow. In this system, the air needed for combustion is made to pass upwards through the grate and the waste lying on top so that the air current passes as an upwards draught through the line of flow of the waste. The object of the incineration process is to obtain a non-combustible residue, the so-called clinker, which contains no residual organlc matter capable of fermentation. In addition, in order that it may be fit for dumping, it must contain no residual, water-soluble, inorganic salts. If this objective is not achieved, undesirable substances may penetrate from the clinker into ground-water. Again, if fermentation takes place on dumping sites, one of the disagreeable consequences is the resulting foul smell.

Besides the requilrements to be met by the clinker, we must also emphasize those which apply to the waste gases. Essentially, in order to protect the environment, they should be cooled and freed from dust and odour.

The principal disadvantages of grate firing to which it is necessary to draw attention are the variable quality of the residues and the particular proneness of the plant to corrosion.

\section{Types of Grate Construction}

Of the varlous systems of grate firing, two may be said to occupy a clearly dominant position, i.e.

1) Firing on a continuous roller grate

2) Firing by means of a mechanical stoker

Apart from these, the 'travelling grate' is a special design which has so far only been made in very limited numbers. Very roughly half the waste incinerating plants now operating with a grate firing system use the roller grate, while the other half are equipped with mechanical stokers. Arguments 
about the advantages of particular designs occasionally verge on the philosophical. The advantage which is constantly claimed for the roller grate is that, at any one time, a large section of the grate is outside the combustion chamber and is able to recuperate. With mechanical stokers the situation is different. These are constantly located in the firing zone and must therefore be made of other, higher quality types of steel than those used for the manufacture of roller grates. On the other hand, the advocates of mechanical stokers emphasize the more uniform and thorough combustion ach i eved.

\section{INCINERATION IN ROTAIING KILNS}

The chlef component in this type of incineration is a cylinder lined with refractory material with a downward gradient in the direction of material flow. This cylinder rotates slowly, thereby constantly mixing and turning over the quantity of waste which it contains. It is just this continual movement and mixing which is one of the principal advantages of the rotating kiln process. The waste is fed in at the upper end of the cylinder, as is also the air needed for combustion. The clinker is tipped out at the bottom end, where the waste gases are also drawn off. At the prevailing firing temperatures of $1,000^{\circ}$ to $1,100^{\circ}$ the metals are reduced to scale. The oxldes blend together with the waste residues to form a waterinsoluble, granular clinker. Since the supply of air can be precisely controlled, it is posslble by correct adjustment to burn even very damp waste without additlonal firing facilities. Problems arise in rotating kilns due to the generation of gases which disturb the temperature in the combustion chamber. In a rotating ki In particular importance attaches to the temperature in this combustion chamber since it is this which directly determines the performance of the kiln. Since the temperature in the combustion chamber is crucially affected by the composition of the waste, any significant change in this requires a corresponding temperature adjustment. The poorer the quality of the waste - the more moisture or ash it contains, for instance - the higher must be the temperature in the combustion chamber. Up to the present time, incineration in rotating kilns is far from winning general acceptance in Community countries. Its share of the total number of waste incinerating plants is well below 10 per cent. 


\section{UL. INCINERATION IN RE-ELOW ROTATING KILNS}

This method of waste incineration is designed to deal with the weak point of incineration in rotating kilns of conventional type, i.e. the generation and combustion of gases. In practical terms it amounts to an improved version of the conventional rotating kiln. The improvement consists in the much more rapid and complete blending together of the gases and the air needed for combustion. In general, this method is regarded as being more easily controlled. Also the performance of the combustion chamber is much greater than with the ordinary rotating kiln and far less dependent on the temperature in the chamber.

Having dealt with waste incineration, we shall now consider the other types of waste processing, which, as we have already pointed out, have not yet acquired any real practical significance.

Firstly, then, let us turn to the metallurgical application of waste. 


\section{The metallurgical use of waste}

By the metallurgical use of waste is meant the reduction of domestic waste by metallurgical means to produce ferrous metal. Use can be made both of the ferrous metal and of the combustible gas generated in the process. The method is roughly as follows: domestic waste is chopped and put into storage to ensure a steady supply of raw material to the metallurgical plant. The waste is then reduced in electric arc furnaces, from which the gas is asplrated. After purification, this gas can be used for heating purposes, and could concelvably be used for generating electricity. If used to produce electriclty, it has been calculated that, in theory, it would cover two thirds of the energy needed to operate the plant (mainly electric arc furnaces).

Besldes the gas, the furnace also yields ferrous metal which can either be tapped off and cast or made into granules in water. The metal may be used later by the steel industry in oxygen converters for melting scrap, or for the reduction of ore. In order to test the feasibility of putting waste to metallurglcal use it would be necessary to build a pilot plant. 


\section{Pyrolysis processes}

Greater attention is currently being paid to the new process of pyrolysis. This is already apparent from the fact that at various places in the Community it is being officially sponsored, and we shall therefore consider pyrolysis below in some detail.

When we talk about pyrolysis as applied to domestic and business waste, we mean the gașification of the waste by the indirect application of heat. In the same way, heat may be applied directly, provided that the supply of oxygen is simultaneously reduced. The technical applications of pyrolysis are by no means limited to the treatment of waste. On the contrary, the concept as used in the petrochemical industry embraces the most diverse fields of technology. Even the gasification of coal under pressure, on which work is at present being carried out, is in essence a form of pyrolysis. If we take a broad view of the objectives to be achieved by pyrolysis in relation to the treatment of waste, we may say that this technology should be applied to the processing of waste in a way which is at once economically beneficial and, in particular, compatible with the protection of the environment.

When we proceed to the (still hazardous) undertaking of defining more closely this generally stated objective of pyrolysis we very soon discover that the new technology is still at the very beginning of its development. Indeed, those who are working on pyrolysis in relation to waste are, in actual fact, aiming at widely divergent goals, however clearly these may be defined. The chief objective, however, is manifestly to find a method of 
treating waste which will render it particularly suitable for dumping. From this polnt on there are obvious differences of opinion. One group comprising both theorists and practical engineers wishes to produce simultaneously from domestic waste a simple fuel gas characterized by a low calorific value. This would have to be used in the vicinity of the producer plant and could not, for example, be fed into a public gas supply system. The other group wishes, in theoretical and practical terms, to produce a high quality gas which could without reservation be fed into the public gas supply network. Which of these two differing aims will gain the upper hand in the course of time is impossible to predict for the time being. It is even impossible to say whether either view will override the other. It would, Indeed, be far more concelvable that, according to the particular circumstances affecting any single location, one or the other set of principles would be applied to the design of any plant using pyrolysis techniques. The principles applied in individual plants would, of course, be dictated by the overall objective adopted in each case. Reduced to its common denominator, the treatment of waste by means of pyrolysis involves charging the waste into a kiln which is then heated indirectly cor directly with the simultaneous reduction of the oxygen supply) so that gasification is effected to the maximum possible extent.

What happens to the gas afterwards - to what extent and by what method it is purified or otherwise treated - depends, as we have already said, on the underlying principle which dictates the mode of operation of the individual pyrolysis plant. Ideally, the process would leave behind a slag which could be safely dumped without further processing. In particular, the pores in the lumps of slag must be sealed to prevent, say, rainwater from leaching out any salts or other substances lodged in the slag which might subsequently percolate through into the ground-water.

A number of German clties are currently engaged in planning the construction and operation of fairly large pilot plants using pyrolysis. In this connection, the chlef concern of the future potential plant operators is to use these plants to collect information about the characteristics of both the slag and the gases produced. Only on the bas is of data obtained over a long period in service do the future potential operators of these plants hope to be able to answer the question whether pyrolys is is, in fact, more economic and more compatible with the protection of the environment than the waste incineration and heat utilization techniques practised hitherto. One of the major objections expressed prior to the construction of the 
large pilot plants by the potential future operators arguing against this technique was that it would be impossible to operate the process on a continuous basis. As with the coke batteries familiar in old gasworks, it would, it was sald, be necessary continually to recharge and remove the slag from pyrolysis kilns. From those quarters of industry engaged in working on pyrolysis techniques comes the answer that, even if it is impossible to employ a continuous process, the charging and cleaning out of pyrolysis ki Ins could probably be automated to a large extent. However, there is a whole band of defenders of pyrolysis techniques who quite openly claim that, in this field too, a continuous process can be expected in the long run.

In addition to doubts about the continuity of pyrolysis processes, potential users frequently call in question the operational reliablitity of pyrolysis plants. A final answer will doubtless have to await the outcome of the long-term operation of the projected pilot plants.

While large-scale pyrolysis plants are still being developed, specialists sometimes advise the building of so-called two-stage equipment. Here, in line with the present state of the relevant technology, coke is produced in the first stage of the process in an indirectly heated, rotating kiln, and this is then gasified in a shaft furnace in the second stage of the operation. Primarlly, this technique is confidently expected to produce an easily controlled, and not excessive, quantity of gas suitable for processing. But opinion is divided about the course which should be followed in the use of pyrolysis. Some potential plant operators would like to take and process the entire quantity of waste, i.e. the conglomerate of household and business waste, straight from the waste collecting vehicle without any pretreatment. Others see pyrolysis as the ideal complement to recycling. They would prefer, in the first place, to separate the waste mechanically and take out certain usable items such as glass, metal scrap, paper and cloth, and then feed the remainder into the pyrolysis plant. Two important advantages are clalmed for this system. Firstly, no useful waste is lost which could be recycled and, secondly, the capacity of the pyrolysis kiln can be much smaller than if the plant had to handle the entire waste conglomerate.

The argument for previous mechanical sorting of the waste before pyrolysis is also supported by a number of purely technical reasons. For instance, none of the metals makes a positive contribution to pyrolysis. They may even reduce the speed of the coking process since, as inorganic 
constituents, they must have the effect of localized inhomogeneities within. the mass of waste. It is therefore sensible to remove the pieces of metal contained in the waste at the outset. A similar argument applies to the glass which is mlxed up in the conglomerate. It is relatively complicated to calculate in advance the advantages and limitations of pyrolysis techniques, since the varlous processes involved, e.g. in organic matter, are far more complex than those which occur in conventional waste incineration, no matter what form this takes.

One of the advantages of pyrolysis over conventional waste incineration which is not disputed by any of the theorists is the fact that, while pyrolysis does generate fumes, these are very much less in quantity than is the case with ordinary waste incineration. There are two reasons why the volume of gas generated by pyrolysis is smaller and more concentrated - and therefore easier to purify and process - than that produced by normal incineration. In the first place, as distinct from incineration, not all the carbon contained in the waste is converted into gas. Up to a fifth remains bonded in the siag. Secondly, in order to ensure the maximum degree of combustion the conventional waste incinerating plant has to operate with a large excess quantity of air, so that the volume of smoke emitted is many times greater than in the case of pyrolysis which does not require any excess air. In the present state of technology it is reckoned that pyrolysis gives rise to only about one tenth of the quantity of gas per tonne of waste generated by the conventional waste incineration process. At the same time, the fumes given off by pyrolysis contain relatively little dust, and this factor, again, is due to the absence of the excess air needed for ordinary incineration.

The large number of development and research projects in the field of pyrolysis has produced the result that, even before the large pilot plants are put into operation, there are both in Europe and the U.S.A. - where pyrolysis has been practised for rather longer - a multiplicity of distinct pyrolysis processes, both in existence and planned.

In one Community country, Denmark, the so-cal led Destrugas-Pyrolysis Process has been developed. Here both heating gas and a substance for soil improvement are produced from waste and sewage sludge as starting materials. The waste is taken from the store and passes via a chopper into the input opening of the vertical pyrolysis kiln. The compartments for the removal of gas are lined with material containing alumina to inhibit corrosion and slagging. 
The waste slides down under its own weight and thus passes through the various heating zones. 400 to $600 \mathrm{Nm}^{3}$ of gas with a calorific value of some $2,700 \mathrm{kcal}$ are obtained from every tonne of waste fed into the kiln. The porous black slag is mixed with sewage sludge and disposed of to farmers to Improve their soil.

In the United States the Garrett Process has been developed and bears the name of the corporation responsible for its development. The purpose of this process is to convert the organic components into oil, while the inorganic constituents such as glass and ferrous and non-ferrous metals have to be separated out. The organic material which remains after this separation is dried and ground. Oil, gas, water and a mixture of solid residues are obtained when this is heated in the pyrolysis kiln with the exclusion of air. If the product of pyrolys is is made to equal 100, then 40 per cent is oil and more than a quarter is gas. This pyrolytic oil can be used later as a heavy fuel oil. It has a very low sulphur content and its calorific value is about half that of comparable 'ordinary' heavy fuel oil. At the same time, special burners are required for burning this oil which is distinguished by its higher viscosity, high oxygen content, and acid properties.

The Landgard Process (belonging to Monsanto), also developed in the United States, works with a horizontal rotating kiln of refractory material. The material fed into and pyrolysed in this equipment leaves the plant via a water bath, where the organic and inorganic constituents are separated. Ferrous metals and glass are salvaged here and the remainder is dumped. It is reckoned that for every 1,000 t of conglomerated waste fed into the plant, 70 t of scrap iron, and $170 \mathrm{t}$ of waste $g$ lass are recovered together with up to 2,100 t of steam as the energy yielded by burning the gas generated by pyrolysis.

Another Community country, France, has produced the so-called Sodeteg Process named after the enterprise commissioned to carry out its development. Fuel gas and solid residues are produced in vertical kilns. It is proposed to use the residues as filter material for effluent purification, and for this purpose the inorganic constituents must be removed beforehand. The plant is heated with gas generated by pyrolysis.

The American Battelle-Northwest Process endeavours to combine pyrolysis with conventional waste incineration. To this end, waste is loaded in at the top of vertically mounted pyrolysis kilns. The waste is dried, pyrolysed and then incinerated in the plant. The necessary temperature is obtained 
by oxidation of the pyrolysate with a steam/air mixture. About 20 to 30 per cent of the waste input stays behind as solid residue.

Also American is the Torrax Process developed by Carborund and Andco. In comparison with other pyrolysis technlques, this is a high temperature process with an operating temperature up to $1,200^{\circ} \mathrm{C}$. In this case, the waste is converted into clinker and gas in a vertical generator vessel lined with refractory materlal. The residue is intended for use as a bullding material, while the gas generated by pyrolysis is used on the spot to produce steam.

Again American in origin is the Purox Process under development by Union Carbide. This also combines pyrolysis with incineration. In this system the waste input is gasified in the upper part of a vertical kiln before the residues are incinerated lower down the kiln with the addition of pure oxygen. The calorlfic value of the pyrolytic gas obtained in this way is sald to be $1,760 \mathrm{kcal}$. This process requires some $200 \mathrm{~kg}$ of pure oxygen to gasify one tonne of waste. This then produces $200 \mathrm{~kg}$ of slag and one tonne of gas. Coollng and purification of the gas alone produce $300 \mathrm{~kg}$ of water and $30 \mathrm{~kg}$ of organic residues.

Owing to the lack of large-scale plants not much can be said yet about the economic viablility of pyrolysis. Its advocates claim that it is more economic than conventional waste incineration. However, it is already clear that increasing the size of plants in order to reduce the unit capltal costs is only possible within comparatively narrow IImits. At the present stage of technological development even large-scale pyrolysis plants will invarlably consist of a large number of separate kilns, so that a very strict Iimitation is imposed on any cost reduction which might be achieved by increasing the size of plants. Within the Community, it is the Federal Republic of Germany which is currently giving the greatest amount of officlal encouragement to pyrolys is technology. 


\section{The combined use of sewage sludge in the treatment of waste}

In principle, it is possible to incorporate sewage sludge into all the processes concerned with the themmal processing of household and business waste. Essentially, this combined treatment involves only a quantitative and not a qualitative modification. Sewage sludge contains organic matter with a calorific value between 3,500 and $5,000 \mathrm{kcal} / \mathrm{kg}$. Hence it contributes a higher calorific value than ordinary conglomerated waste. In those areas of the EEC where coal mining is carried on, and where sludge is also drawn from the coal washing plants, the calorific values are substantially higher than those given above.

The reason why sewage sludge is not incinerated together with household and business waste on a much larger scale than hitherto is its high water content. Compacted sewage sludge still retains 60 to 65 per cent water, which it is almost impossible to reduce by mechanical means. Even using chemical conditioning it is hardly possitle to bring down the water content of sewage sludge below 50 per cent. The disadvantage of the high water content so far as the incineration process is concerned is that the evaporation of the moisture ties up a great deal of the process heat. There are other disadvantages from the point of view of process technology for which no satisfactory solution has yet been found. On this subject, the fcllowing points should be made:

If domestic waste is fed into an incinerating plant together with sewage sludge the so-called 'steak effect' generally occurs rapidly. Under the intense heat, the surface of the sludge quickly bakes while the inside 
of the sludge remains unburnt and relatively moist. The result is a dumping materlal which gives rise to all the disagreeable features of putrefaction - including the foul smell.

since, therefore, waste and sewage sludge are incompatible as a combined feed materlal for incinerating plants, quite differently conceived methods must be evolved for burning the sludge. These may, for example, take the form of drying the sludge at high temperature until such time as it may be injected as dust into the combustion chamber. It is true that, in this process, the steam originating from the drying of the sludge is also blown into the combustion chamber and there reduces the calorific value to an average between 3,000 to 4,000 $\mathrm{kcal}$. The pressure to develop suitable incineration techniques for sewage sludge is due principally to the increasing volume which at present has to be dealt with. One of the solutions attempted in practice involves using the heat generated by burning the waste to treat the sludge. The sludge processed in this way is not, however, subsequently burnt together with the waste but is supplied to farmers to improve their soil. 


\section{Heat utilization in waste incineration}

There are a number of ways in which use may be made of the heat energy generated by waste incineration - and of the low-value heating gases to be obtained later by pyrolysis. These are basically the following:

1) Use in power stations

2) Use in combined thermal-electric power stations

3) Use in the supply of long-distance heating

4) Use in power stations supplying long-distance heating

5) Use for generating electricity within the incinerating

$$
\text { plant itself }
$$

For those pyrolysis plants which, later on, will be producing high quality gases there is the sixth possibility of feeding this high quality gas into the public gas supply network. Within the EEC at the present time it is probable that most of the heat energy generated by waste incineration is used in power stations and the supply of long-distance heating. At first, in many waste incinerating plants no use was made of the heat energy generated. In the long run, however, such. neglect could not make sense since, as a rule, these plants have only two sources of income available to them, apart of course from the charges made for collecting the waste. These sources are the selling of scrap and the sale of energy (if we disregard for the moment the income arising from the sale of broken glass and waste paper, which has so far not acquired much significance).

Apart from this economic argument in favour of utilizing the heat energy generated in the plants, there is also a technical reason for this. 
We are faced with the following situation: waste incinerating plants must all be operated at very high temperatures in order to ensure the complete Incineration of the conglomerated waste. For example, in the Federal Republic of Germany a minimum temperature of $850^{\circ} \mathrm{C}$ has been laid down by the authorities. In practice, the actual operating temperatures often far exceed the minima, and may in some cases reach around $1,100^{\circ}$. After incineration, the gases produced by combustion must be passed through electrofilters to protect the environment. For technical reasons, the inflow temperature into these filters must not exceed $300^{\circ} \mathrm{C}$. Therefore, the inclnerating plants are literally forced to effect substantial cooling between the combustion chamber and the electrofilters. Now this cooling operation can be performed particularly efficiently with the help of a steam boiler and by removing heat in this way the damage caused to the incinerating plant by heat corrosion is reduced.

Using the energy derived from waste incineration within the plant itself will only be worthwhile in relatively few cases. A plant generatingstation, l.e. one producing electricity for use in the plant itself, is often not viable owing to the inadequate size of the plant.

Direct utilization of the steam, e.g. for process heat or heating systems, requires customers in the immediate vicinity of the plant. In practice, therefore, the most senslble solution is to leave to third parties the use of the energy generated. This, too, is not without its problems, naturally, and these apply in particular to the disposal of steam, which is the principal product. Because of the limited possibilities of carrying steam over long distances, the customers must not be located too far away from the incinerating plant. A further unhelpful fact is that the operation of incinerating plants is most economic if they run continuously throughout the year. This means, however, that steam continues to be produced the whole time in more or less the same quantity. The power stations on the recelving end cannot therefore use the generating capacity of incinerating plants to fall back on in times of peak demand but must accept this supply of energy regularly and continuously irrespective of their own requirements. Naturally, a similar situation applies to the supply of steam to large longdistance heating systems. Here, the requirements of heat energy fluctuate between extremes according to the time of the year, whereas the supply of steam from the incinerating plant remains fairly constant whatever the season.

The situation as it affects the gas generated by pyrolys is differs 
only to a limited extent. If the plant produces high quality gas which may be fed into the public supply network, then this can only happen if such a network exists. If a simple heating gas is produced, this calls for a sufficlently large consumer of such gas in the neighbourhood of the pyrolysis plant.

Depending on the potential applications available to the individual incinerating plant for the energy which it generates, a cholce can be made between higher steam pressure and higher superheating. Considerable improvements have been achleved over the last few years as regards the amount of steam produced. Even as recently as ten years ago it was reckoned that the incineration of one tonne of waste would yield about one tonne of steam. The improvement achleved in the meantime is due both to technical refinements in waste incinerating plants and to the higher calorific values of today's waste. To obtain two tonnes of steam from the input of one tonne of waste is no longer exceptional by any means. 


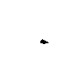


Procurement of raw materials and energy is one of the most serious problems of our time, especially in the industrialized countries and since 1973, when the great energy crisis broke, there has been a growing awareness of the fact that greater care must be taken in the use of raw materials and energy. The 'throw-away age' is past. The magic word 'recycling' has come to replace the 'waste society'. Household and industrial waste is collected and either recycled or converted into energy.

Both processes will be combined to an increasing extent with a view to achieving a complete recycling system.

The recovery and recycling of raw materials is increasing in importance: paper and cardboard are collected; used oil is re-refined; glass fed back into glassworks; animal corpses are processed into meat meal; old cars are shredded; kitchen and garden waste is composted; etc. Other recyclable materials, such as magnetic metals, aluminium, copper, brass and tin are also recovered from refuse.

Total recycling of all waste raw materials is not possible. The remaining waste is avallable, then, for energy production. Various methods are used for this purpose: in addition to the best known - incineration in refuse inclnerators to produce steam and electricity - there are others, e.g. pyrolysis, by whlch synthetic gases or liquid fuels are reproduced, and blological conversion, in combination with sewage sludge, to produce methane. The synthetlc gas obtained by pyrolysis can also be turned into methane or methanol. Refuse incineration is also combined with the use of 
conventional fuels. The conventional secondary fuel - pulverized coal, natural gas or heavy oll - serves to iron out the irregularities in heat release which Inevitably attend refuse incineration, so that the steam conditions required to drive a turbine are produced. The conventional auxiliary fuel is burned el ther in a separate combustion chamber in the same boller or in the same combustion chamber as the refuse.

Refuse was a source of energy in many Western European countries long before the so-called oll crisis occurred, so that refuse was put to good use. Amsterdam, for example, has been incinerating its refuse for sixty years to produce steam which drives turbines to generate electricity. Geneva and Zurich do likewise.

In the extraction of energy from refuse, the useful energy is always proportional to the product of the amount of refuse and its lower calorific value. The ratio depends on the thermal efficiency of the incineration plant and is therefore varlable: it may be as high as 0.7 , depending on the incineration process used and certain technical details such as boller design, furnace design, the flue gas purifying system, etc.

Experience has shown that the amount of waste in industrialized regions generally varies between 200 and $300 \mathrm{~kg}$ per inhabitant and per year; in highIy industrlalized areas the figure may even rise to $450 \mathrm{~kg}$ per inhabitant and per year. Of this, 70-80 per cent is household waste, the remaining 20-30 per cent trade and/or industrial waste.

The useful energy content, in terms of calorific value, is $7,100-9,600$ $\mathrm{kJ} / \mathrm{kg}$ for household waste, and 9,600-15,000 kJ/kg for trade and/or Industrial waste. Nowadays solid waste can be expected to yield an average of $6,000 \mathrm{~kJ} / \mathrm{kg}$. With a per-capita average of $250 \mathrm{~kg}$ of waste per year, the useful energy (also per caplta and per year) can be calculated as follows: $0.7 \times 250 /$ per inhabitant per year $\times 8,000 \mathrm{~kJ} / \mathrm{kg}=1.4 \times 10^{6} \mathrm{~kJ} / \mathrm{per}$ inhab itant per year.

By way of comparison: the average energy consumption in industrialized regions, broken down into electricity consumption and the consumption of liquid fuels, is as follows:

Electricity consumption: $13 \times 10^{6} \mathrm{~kJ} /$ per inhabitant per year; Consumption of energy produced from liquld fuels: $54 \times 10^{6} \mathrm{~kJ} / \mathrm{per}$ Inhab itant per year;

Total energy consumption per inhabitant per year: $67 \times 10^{6} \mathrm{~kJ} / \mathrm{per}$ inhabitant per year. 
Liquid fuels comprise:

- all grades of fuel oll $63 \%$

- diesel oll, petrol, aviation spirit 29\%

- oll for the generation of energy 4\%

- mineral oll for technical purposes 4\%

$100 \%$

The figure glven, i.e. $54 \times 10^{6} \mathrm{~kJ} /$ per inhabitant per year, was calculated on the basls of an average thermal efficlency of 60 per cent and therefore reflects only the actual useful thermal energy obtained from liquid fuels.

The ratio of refuse-derlved energy to actual energy consumption is therefore:

$$
\frac{1.4 \times 10^{6}}{67 \times 10^{6}} \times 100=2.1 \%
$$

From experience so far with the use of waste for energy production in incineration plants - all the other methods are still in the research or development stage - it may be concluded, from the energy viewpoint, that where local clrcumstances permit and the necessary conditions are met, an effort should definitely be made to convert waste into thermal energy in the form of steam. This can be accomplished with considerably greater thermal efficiency.

If all the energy in the steam were supplied to the consumer (industry, distrlct heating, etc.l as heat - i.e. in the form of steam or hot water, without being converted to electricity via a turbine - energy derived from waste might be raised to a respectable 2-2.7 per cent the total energy consumed. These figures show that by using the most rational methods of conversion a not insignificant proportion of total energy consumption can be covered by energy produced from waste. 


\section{.}


CDNA05609ENC 